Article

\title{
Solar Photovoltaic Development in Australia-A Life Cycle Sustainability Assessment Study
}

\section{Man Yu ${ }^{1, *}$ and Anthony Halog ${ }^{2}$}

1 Institute of Systems Sciences, Innovation and Sustainability Research (ISIS), University of Graz, Merangasse 18, Graz 8010, Austria

2 School of Geography, Planning and Environmental Management, The University of Queensland, Brisbane, QLD 4072, Australia; E-Mail: a.halog@uq.edu.au

* Author to whom correspondence should be addressed; E-Mail: mandyyu127@gmail.com; Tel.: +86-186-1270-5581.

Academic Editor: Giuseppe Ioppolo

Received: 31 October 2014 / Accepted: 9 January 2015 / Published: 23 January 2015

\begin{abstract}
Australia possesses the highest average solar radiation of any continent in the world, but solar energy in total contributes less than 1\% to Australia's primary energy consumption. This study intends to assess whether solar photovoltaic (PV) is really a sustainable option for Australia's energy transition on the project level. A life cycle sustainability assessment (LCSA) was conducted on a 1.2 MW flat-roof mounted PV solar array called UQ Solar, and the results suggested UQ Solar performed well in environmental aspects, except for emissions of several criteria air pollutants. It was economically feasible only with the grant provided by the Queensland government and the levelized cost of electricity (LCOE) was more or less the same as the LCOE of offset electricity. However, its social performance was not as good as expected. Large-scale PV installations can be sustainable in Australia on several conditions. PV manufacturers should be more responsible for reducing the use of hazardous materials; end-of-life treatment should be taken good care of; government should truly support the deployment of large-scale PV installation by providing more incentives and infrastructures; substantial subsidies for fossil fuel power stations should phase out; more awareness and training activities should be organized to promote social acceptance.
\end{abstract}

Keywords: LCSA; solar PV; UQ Solar; energy payback time (EPBT); LCOE; grid parity; social sustainability; Australia 


\section{Introduction}

Australia is a country with abundant energy resources, and more than three quarters of energy resources is exported [1]. While substantially utilizing vast amount of fossil fuels, various renewable energy resources are largely undeveloped in Australia, except for hydro and wind [1]. A transition to lower-emissions fuels is expected to take place to tackle severe impacts of global warming. Among various kinds of renewable energy, solar energy has great potential to be an abundant, clean and reliable energy resource. Australia, in particular, has great advantages of deploying solar energy, as she possesses the highest average solar radiation of any continent in the world [2]. However, in fact, solar power in total contributes less than $1 \%$ to Australia's primary energy consumption [3], and it is predominantly used for solar thermal water heating [1].

Photovoltaic (PV) is the direct use of solar radiation to generate electricity. Different types of PV installations have been exploited for several decades in Europe, which has proven the reliability of the technology itself. However, large-scale diffusion of PV installations in Australia is still very limited. It is, therefore, of strategic importance to figure out whether solar PV is really (can be) a sustainable option for Australia's energy transition. Life cycle sustainability assessment (LCSA) was selected in this study with the aim to analyze the sustainability of the PV system in Australia on the project level. The deliverables of this study are helpful in realizing current environmental, economic, and social hotspots of PV installations in Australia on the project level. Feasible solutions were proposed as well to help to achieve large-scale diffusion in the near future. In addition to that, this study was an attempt to put LCSA into practice. Both merits and limitations were disclosed, which would possibly enhance further development of LCSA methodology by learning lessons from practical application.

Developed from ISO standard life cycle assessment (LCA), LCSA is more inclusive and comprehensive as it covers more aspects relating to sustainability, which reflects the paradigm shift from environmental protection towards sustainability [4]. However, research community in the area of LCA has not reached consensus on what LCSA actually constitutes and how LCSA should develop in the future. Three main streams are observed: the first stream is influenced by Kloepffer's [5] definition on LCSA, which only highlights the inclusion of all three pillars of sustainability; the second stream is oriented at CALCAS (Coordination Action for Innovation in Life Cycle Analysis for Sustainability) project, which understands LCSA in a broader scope and in further detail [6]; and the third stream is developed by Halog and Manik [7], which emphasizes interrelationships and system dynamics in the assessment. To make this study feasible to conduct, LCSA guidelines developed by the UNEP/SETAC life cycle initiative [8] were employed. Similar to Kloepffer's definition, three dimensions of sustainability were assessed respectively from the life cycle perspective before they jointly formed a holistic LCSA. Each dimension went through four interdependent and iterative phases, which were goal and scope definition, life cycle inventory analysis, life cycle impact assessment and interpretation.

As a relatively new methodology, very few researches have been conducted to apply LCSA to solar PV systems. Most previous studies have only focused on LCA of solar PV systems and the results are various in terms of primary energy consumption, greenhouse gas (GHG) emission, and energy payback time (EPBT). Alsema [9] reported, under Southern European conditions, the primary energy consumption for rooftop mounted multi-Si PV modules with the efficiency of $13 \%$ was $4200 \mathrm{MJ} / \mathrm{m}^{2}$, which corresponded to the EPBT of 2.5 years, and GHG emission of $46 \mathrm{~g} \mathrm{CO}$-eq./kWh. Meijer et al. [10] 
reported a slightly higher energy demand of $4900 \mathrm{MJ} / \mathrm{m}^{2}$ for multi-Si modules with the efficiency of $14.5 \%$, and the corresponding EPBT was 3.5 years under the Netherlands' conditions. Jungbluth [11] estimated, under the environmental conditions of Switzerland, for various multi-Si PV modules, the GHG emissions ranged from $39 \mathrm{~g} \mathrm{CO}_{2}$-eq./kWh to $110 \mathrm{~g} \mathrm{CO}_{2}$-eq./kWh and the EPBT was 3-6 years, depending on configuration of the PV systems. With material-inventory data from industry, Alsema and de Wild-Scholten [12] demonstrated much lower primary energy demand and GHG emission of complete rooftop Si-PV systems. Fthenakis and Alsema [13] also reported the GHG emission of a rooftop multi-Si application was $37 \mathrm{CO}_{2}$-eq./kWh in 2004-2005, and the corresponding EPBT was 2.2 years under Southern European conditions. De wild-Scholten [14] updated these estimates in 2009 based on thinner modules and higher efficiency. An EPBT of 1.8 years and GHG emission of $30 \mathrm{~g} \mathrm{CO}_{2}$-eq./kWh for both multi- and mono-Si PVs were reported.

By conducting LCSA on a representative solar PV project in Australia, this study is expected to find out principal problems regarding solar PV's environmental bearability, economic viability and social equitability [15], and hopefully, the results can be helpful for large-scale diffusion of solar PV system in the near future.

\section{Case Study}

A LCSA was carried out on a 1.2 MW photovoltaic solar array named "UQ Solar". It is located at St. Lucia campus of the University of Queensland, and it was selected for several reasons. First of all, Queensland State is also known as "Sunshine State", and it is the state that has the highest installed PV generation capacity in Australia [16], thereby choosing one case coming from Queensland makes more sense. Second of all, this solar array is Australia's biggest flat-panel PV power system, which is almost 25\% larger than any other rooftop system in Australia [17], indicating it well represents this type of solar PV system in Australia. Thirdly, grid connected distributed PV systems have represented the largest share (>97\% in 2012) in Australia since 2009 [18], and UQ Solar falls into this category. Lastly, this project is easily accessible for the author to collect necessary information and data.

More than 5000 polycrystalline silicon solar panels covering $8200 \mathrm{~m}^{2}$ of roof space have been installed across four major buildings: the UQ Centre, two adjacent multi-level car parking buildings, and the Sir Llew Edwards Building. It also has a small experimental array on the Prentice Building and a novel concentrated PV tracking array alongside Sir Fred Schonell Drive [17]. For the purpose of simplification, only solar panels on the four major buildings were considered in this assessment.

The UQ Centre has the University's largest PV installation rated at $433.44 \mathrm{kWp}$ on its extensive and gently sloping roof area, and 1806 modules in total occupy $2956 \mathrm{~m}^{2}$ of roof area [17]. When the peak output of the rooftop PV system exceeds the electricity demand of UQ Centre, power is exported and distributed to other nearby buildings using University's low voltage electricity network [17].

Taking up $4610 \mathrm{~m}^{2}, 2824 \mathrm{PV}$ modules rated at $338.9 \mathrm{kWp}$ have been installed on the undulating roof of multi-level carparks $1 \& 2$. Panels on the north edge of the building have been placed parallel with the roofline. To deal with the undulating roof and small differences in roof level, the other panels are placed on tilt frames [17].

Taking up $612 \mathrm{~m}^{2}, 374 \mathrm{PV}$ modules rated at $89.76 \mathrm{kWp}$ have been installed on the roof of Sir Llew Edwards building. Most of the solar panels were laid flat or parallel to the roof. A small installation of experimental panels has been placed on tilt frames [17]. 
To sum up, the defined PV system consists of 5004 Trina TSM 240-PC05 polycrystalline modules, 85 Aurora Power-One PVI-12.5-OUTD/-S inverters, and 6 Aurora Power-One PVI-5000-OUTD inverters.

\section{Methodology}

\subsection{Environmental Life Cycle Assessment}

Environmental LCA is a technique that is used to assess the environmental impacts associated with a product over its life cycle. As mentioned above, an environmental LCA should be carried out in four phases.

In goal and scope definition, assessment context needs to be provided, and detailed technical information needs to be specified, including functional unit, system boundaries, reference flow, allocation methods, assumptions and limitations [8].

In inventory analysis, all LCI data for the specific case are collected from the comprehensive Ecoinvent database version 3.1 [19], and the activity name is "electricity production, photovoltaic, $3 \mathrm{kWp}$ flat-roof installation, multi-Si". This dataset is intentionally made for Australia, and necessary adaptations, which are mentioned in the assumptions supplemented in the end of this article, have been made.

In life cycle impact assessment, all data collected in inventory analysis are inserted into SimaPro 7.3. Primary energy consumption is calculated and CML 2 baseline 2000 V2.05 is employed to assess some mid-point environmental impacts.

In interpretation, energy payback time (EPBT) is calculated to indicate the number of years taken by UQ Solar to compensate for the energy that was consumed to manufacture the entire system.

\subsection{Life Cycle Costing}

Originally developed from a strict financial accounting practice, life cycle costing (LCC) is the oldest technique of the three. Traditionally speaking, LCC is an aggregation of all costs that are directly linked to a product over its entire life cycle. However, recently, it also takes into account external relevant costs and benefits that are anticipated to be privatized [8]. Like LCA, LCC is carried out in four phases.

In goal and scope definition, similar elements described in LCA need to be clarified in LCC.

In inventory analysis, three major types of data are collected: (1) Weather data: RMY Australia Representative Meteorological Year Climate Files [20] are used as the input to the weather data. Weather file of Brisbane is selected in particular for this analysis; (2) Technical performance data: technical datasheets of the specific PV module and inverters are used as references when entering relevant technical parameters. Even though the specific input variables (from CEC performance model) are not exactly the same as those put in the datasheets, the overall results are well simulated, indicating those trivial differences only have insignificant effects; (3) Financial performance data: Most of the financial input parameters and assumptions are collected from APVA [21] and Australian Bureau of Resources and Energy Economics [22]. Some reported data from AUSTELA [23] are also very useful. After collecting all necessary data, they are modeled into System Advisor Model (SAM 14 January 2014) to deliver all results. The SAM model has a performance model and a financial model. When inserting technical parameters and a set of weather data, the performance model can calculate the output of a 
renewable energy system [23]. Based on the performance model and some financial parameters, the financial model can further calculate the financial performances of the studied system [23].

In life cycle impact assessment, a number of widely used financial metrics are calculated using SAM, including LCOE, electricity cost per year, net present value, payback, after tax cash flow, and cost per Watt.

In interpretation, grid parity is analyzed, followed by verification and limitation analysis.

\subsection{Social Life Cycle Assessment}

The UNEP/SETAC guidelines [8] state S-LCA conforms to the ISO 14040 framework with some adaptations. Again, four phases are carried out in an S-LCA.

In goal and scope definition, system boundary, stakeholders, subcategories, and limitations are stated.

In inventory analysis, information is collected based on stakeholders and subcategories identified, and the information basically comes from reports, websites and literatures.

Life cycle impact assessment is quite flexible in S-LCA, as UNEP/SETAC Guidelines [8] do not specify what should be done in this phase. This impact assessment can be either specific or general, depending on how much data is available. A nine-color qualitative assessment is adopted in this phase to assess the social impacts of UQ Solar.

Interpretation is given based on inventory results and impact assessment. Significant issues are identified, the study itself is evaluated and conclusions or recommendations are made.

\section{Results}

\subsection{UQ Solar LCA}

\subsubsection{Goal and Scope Definition}

The following parameters were collected according to Fthenakis et al. [24]:

(1) Location and on-plane irradiation level

The approximate location of this system is $\left(153^{\circ} \mathrm{E}, 27^{\circ} \mathrm{S}\right)$, and the yearly average irradiation collected by modules is $186 \mathrm{~W} / \mathrm{m}^{2}$. Annual average power produced per area is $146.6 \mathrm{~W} / \mathrm{m}^{2}$ [17].

(2) Module-rated efficiency: $14.7 \%$ [25]

(3) System's performance ratio: 0.75 [26]

(4) Time-frame of data: June 2010-June 2040

(5) Expected lifetime and degradation ratio for PV and balance of system (BOS)

PV module warranties: 30 years with $2 \%$ of modules repaired and $1 \%$ reject [25]

Degradation ratio for PV: $0.7 \%$ per year [25]

Inverters: 15 years with one repair in the lifetime [26]

Electric installation: 30 years [26]

Mounting structure: 30 years [26]

Manufacturing plants (capital equipment): 30 years [26]

(6) Average grid electricity mix

Although UQ Solar is located in Brisbane, Australia, PV modules used are produced in China. Therefore, China average grid electricity mix $(79 \%$ hard coal $+16 \%$ hydro $+3 \%$ oil $+2 \%$ 
nuclear) [27] is used to analyze environmental impacts generated from PV modules production, while Queensland average grid electricity mix $(72 \%$ black coal $+15 \%$ natural gas $+10 \%$ coal seam methane $+1 \%$ bagasse $+1 \%$ hydro $+1 \%$ photovoltaic) [27] is used to assess other life cycle processes.

System boundary includes raw material acquisition, material processing, product manufacturing, installation, operation, maintenance, end-of-life treatment and disposal for both PV modules and BOS. Transportations between each of the unit processes are also included.

The main function of a solar PV system is to produce electricity. The functional unit is thus $1 \mathrm{kWh}$ of electricity produced by UQ Solar.

Referring to $1 \mathrm{kWh}$ of electricity produced by UQ Solar, the amount of materials, products and systems needed are calculated in Figure 1. A $3 \mathrm{kWp}$ module has been chosen as the basic module. Larger system can easily be scaled from the $3 \mathrm{kWp}$ module without producing a significant error [27].

Ordinary by-products are allocated between products based on their economic values, heating values or mass values. For recyclable materials, the primary producer does not receive any credit for the provision of any recyclable materials. For wastes, the treatment of wastes is completely allocated to waste producer, and the producer does not receive any credit for recycling products generated out of waste treatment [28].

Due to the time restriction and budget limitation, most of the data are collected from existing databases with appropriate adaption to Australian situations. However, still, there are some mismatches between the data in databases and the data in real case, besides the assumptions made. For example, the cell efficiency in fact is slightly higher than the one assessed in the database, which indicates the emissions should be slightly lower in reality; the capacity in the database is $210 \mathrm{Wp}$ [27] while in real case it is $240 \mathrm{Wp}$ [17]; annual average solar irradiation in fact is $186 \mathrm{~W} / \mathrm{m}^{2}$ [17] which is higher than the assumption made in the database; electricity production assumption in database is $1407 \mathrm{kWh} / \mathrm{kWp}$ [27], while in fact it is $1475 \mathrm{kWh} / \mathrm{kWp}$ [17].

Therefore, the results of this life cycle assessment should be read with great caution, even though the simulation has been designed as case-specific as possible.

\subsubsection{Life Cycle Inventory Analysis}

Table S1 presents the mass of criteria air pollutants and greenhouse gases released at every stage of the life cycle of the 1.2 MW PV system. In this inventory table, carbon dioxide biogenic, land transformation, carbon monoxide biogenic, and methane biogenic are excluded. It is evidently clear that, except for $\mathrm{CO}$ and $\mathrm{SO}$, the production of PV modules caused the highest amount of air emissions among all life cycle stages. Table S2 presents emissions avoided (or increased) due to the installation of UQ Solar by comparing emissions of two electricity generation systems that are UQ Solar PV system and conventional Queensland electricity grid system. Emissions generated from UQ Solar system were obtained from Ecoinvent database version 3.1 with the activity name of "electricity production, photovoltaic, $3 \mathrm{kWp}$ flat-roof installation, multi-Si", while the emissions of conventional grid system were derived from AusLCI database, and the comparison was made on the basis of $1 \mathrm{kWh}$ of electricity generation. Figure 2 demonstrates the emissions of two systems in relative terms [29]. For each type of air emission, $100 \%$ is assigned to the system that emits more. It is easy to observe UQ Solar has higher emissions of 
As, $\mathrm{Cd}, \mathrm{Cr}, \mathrm{Pb}$ and $\mathrm{C}_{6} \mathrm{H}_{6}$ along its life cycle, while conventional Queensland grids have higher emissions of $\mathrm{Hg}, \mathrm{CO}, \mathrm{PM}_{10}, \mathrm{NO}_{x}, \mathrm{SO}_{x}, \mathrm{CO}_{2}$ and $\mathrm{CH}_{4}$. A possible explanation could be $\mathrm{PV}$ modules production consumes more hazardous materials of certain kinds [30].

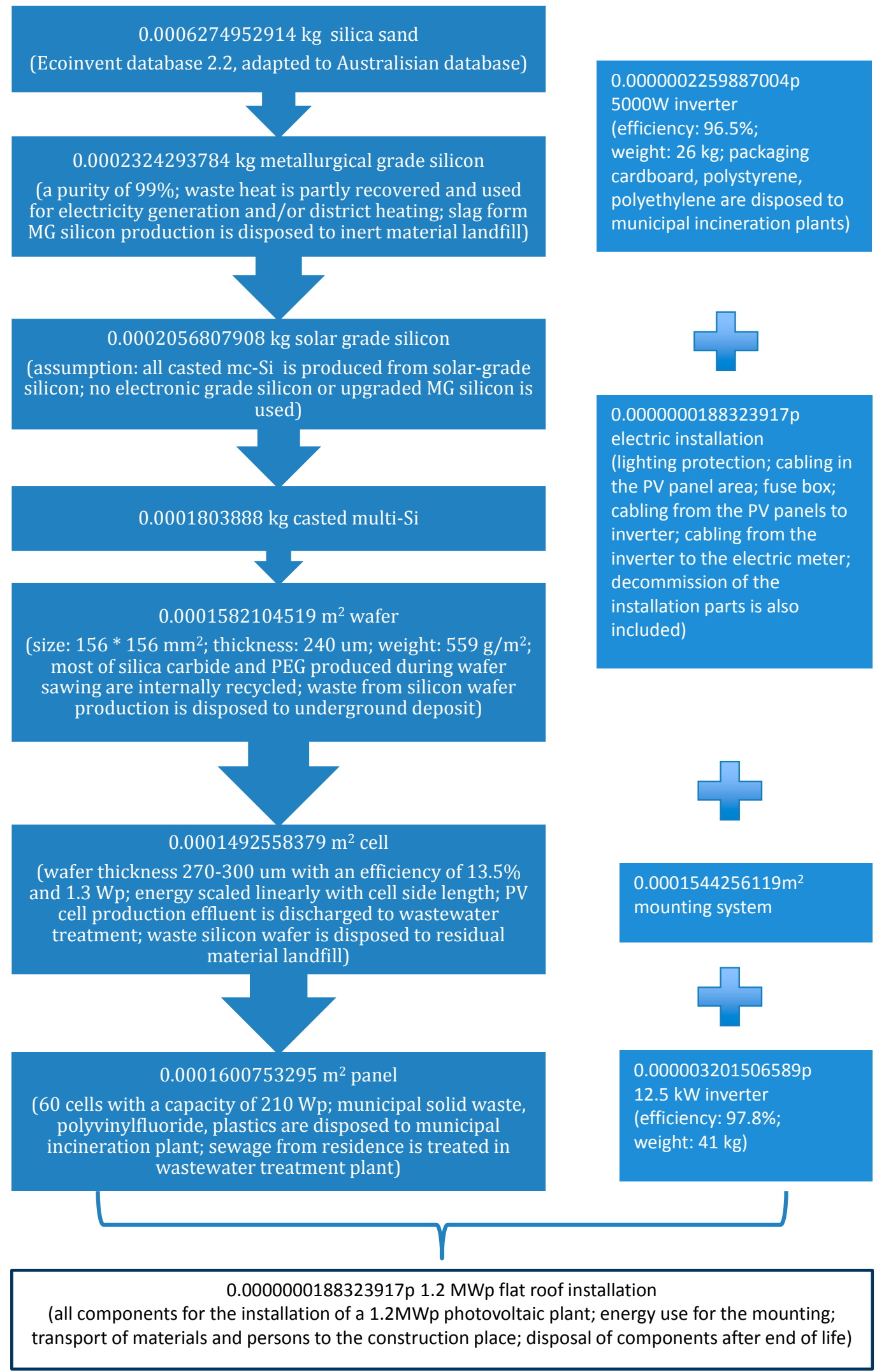

Figure 1. Reference flow in life cycle assessment of UQ Solar. 


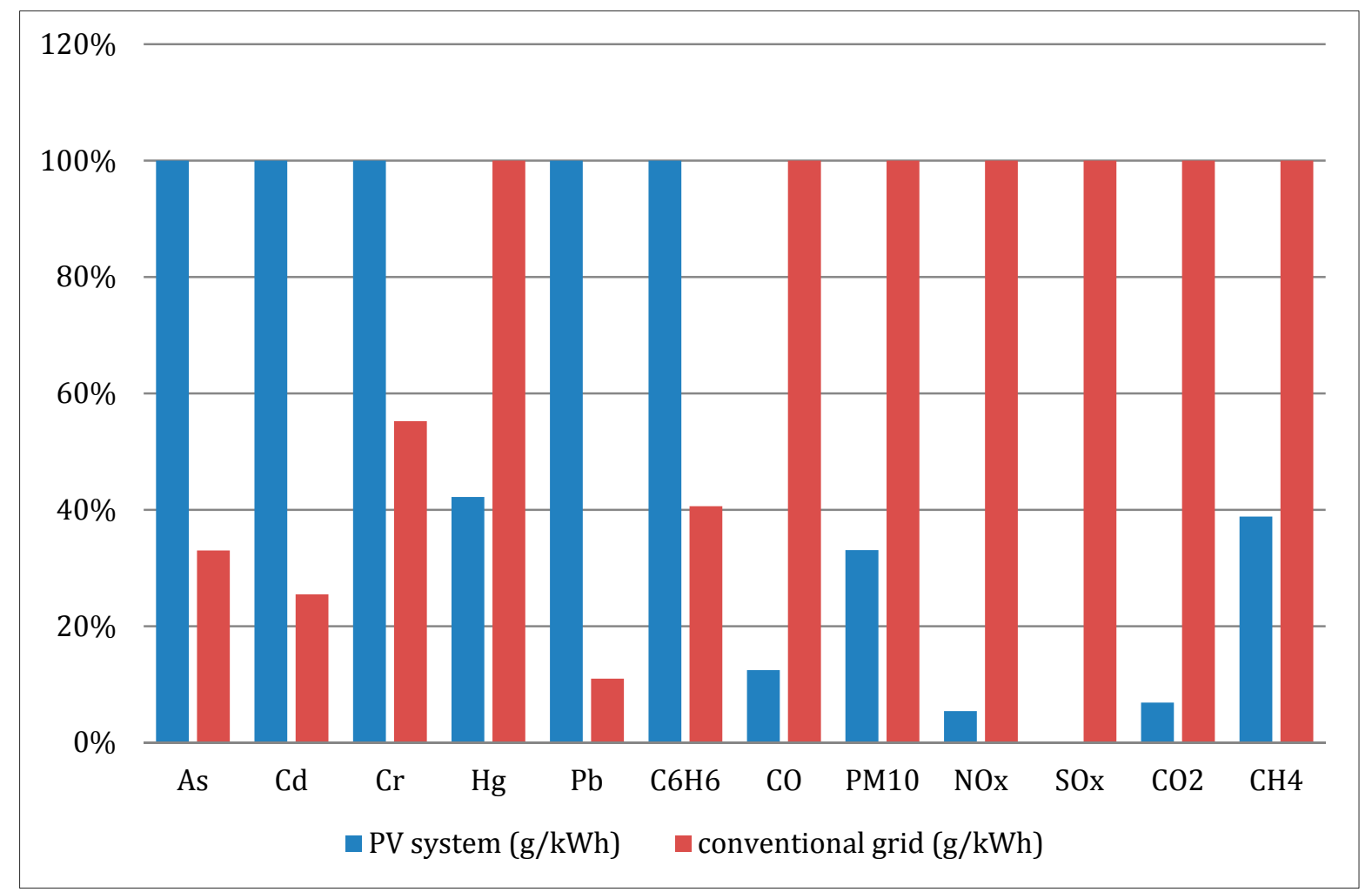

Figure 2. Air emission comparison between two electricity generation systems.

\subsubsection{Life Cycle Impact Assessment}

The primary energy demand for the defined PV system consists of modules manufacturing, mounting system production, inverters production, electric installation, transportation energy, operation and maintenance energy, as well as end-of-life energy demand. They are modeled using SimaPro 7.3, and the total primary energy (or equivalent primary energy) consumption (after neglecting operation and maintenance energy) of the PV system is $4.92 \times 10^{7} \mathrm{MJ}, 82.3 \%\left(4.05 \times 10^{7} \mathrm{MJ}\right)$ of which is for PV modules production. One module consumed approximately $8094 \mathrm{MJ}$ primary energy, and each module occupies $1.6368 \mathrm{~m}^{2}$; therefore, $1 \mathrm{~m}^{2}$ module needs $4945 \mathrm{MJ}$ primary energy, and $21 \mathrm{MJ}$ primary energy is consumed per peak power.

In addition, CML 2 baseline 2000 V2.05 is employed to assess some mid-point environmental impacts. Table S3 shows the results that are obtained after classification and characterization. For the majority of categories, PV modules production makes the biggest contributions. However, for fresh water aquatic ecotoxicity and marine aquatic ecotoxicity, electric installation contributes more. For human toxicity, mounting system also has significant impact, besides PV modules production and electric installation. Table S4 compares life cycle impacts imposed by UQ Solar and conventional grid electricity production. Figure 3 demonstrates the impacts of two systems in relative terms. For each category of impact, 100\% is assigned to the system that generates severer impacts. It is observed, except for ozone layer depletion, conventional grid generates far more environmental impacts in all categories. In 30 years' lifetime, UQ Solar can reduce the global warming impacts by decreasing 40,345.84 tons of $\mathrm{CO}_{2}$-eq emission. 


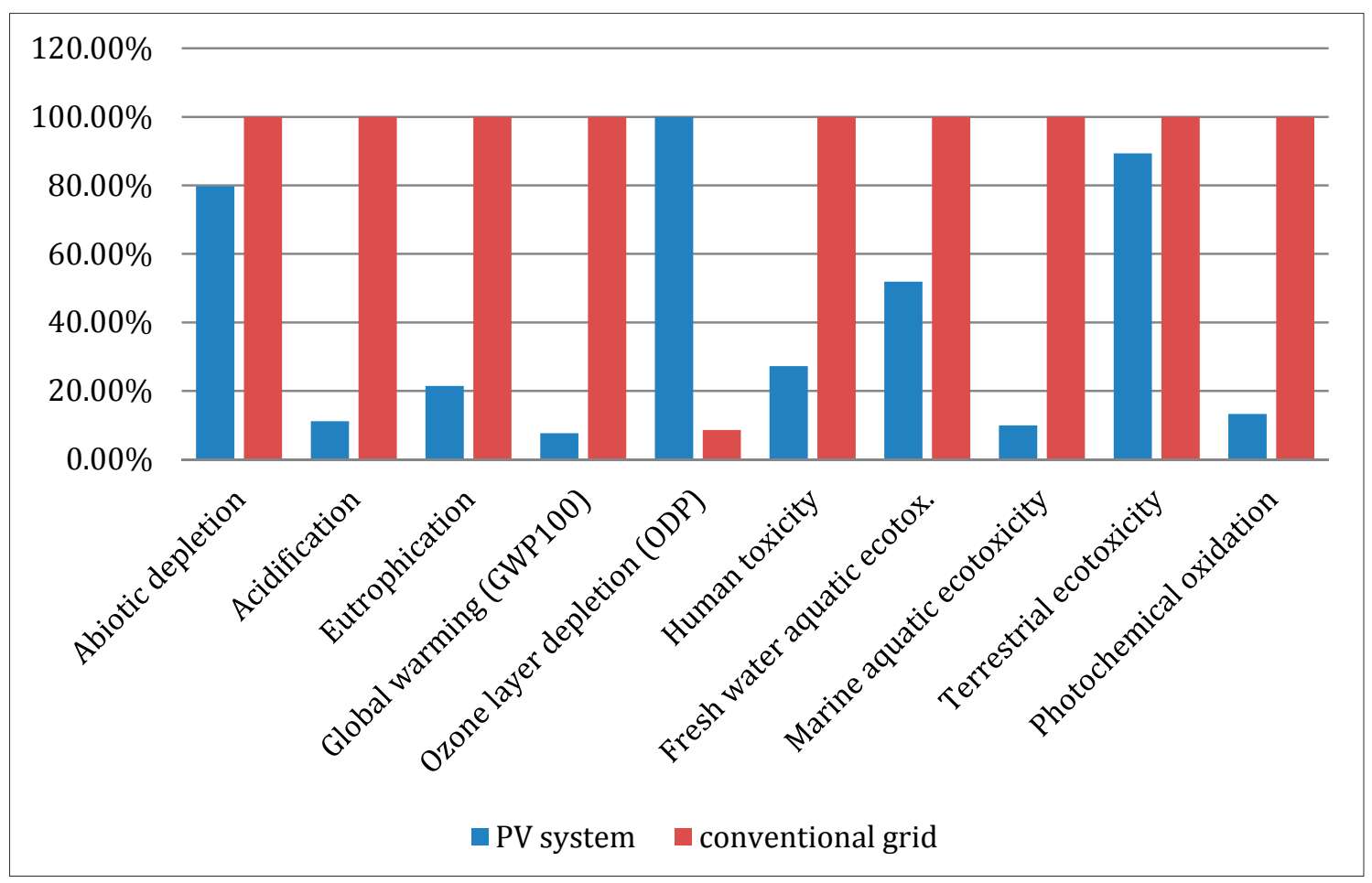

Figure 3. Life cycle impact assessment comparison.

\subsubsection{Interpretation}

It is known the total primary energy consumption is $4.92 \times 10^{7} \mathrm{MJ}$, and the annual energy output of the system is $1770 \mathrm{MWh}(1 \mathrm{kWh}=3.6 \mathrm{MJ})$. If a degradation rate of $0.7 \%$ in cell output efficiency per year is taken into account, the EPBT is 7.91 years calculated by Microsoft Office Excel. In some cases, the electricity output at the demand side needs to be converted back to its equivalent primary energy by grid efficiency $\eta_{\mathrm{g}}$ before calculating EPBT. Assuming $\eta_{\mathrm{g}}=0.3$ [26], EPBT is then calculated with the following formula:

$$
\operatorname{EPBT}(\text { years })=\frac{E(\text { modules })+E(\text { mounting })+E(\text { inverter })+E(\text { installation })+E(\text { transportation })}{\frac{\text { annual } E(\text { out })}{\mathrm{g} g}}
$$

In these cases, the EPBT becomes 2.33 years.

All in all, the results of UQ Solar LCA are comparable to the results given from previous studies. For example, the EPBT in our study is 2.33 years when taking grid efficiency into account, while the results of other literatures are between 1.8 years and 3.5 years $[9,10,13,14]$.

\subsection{UQ Solar LCC}

\subsubsection{Goal and Scope Definition}

The main goal is to assess the economic performance of the system over its entire life. Main cost categories are quantified and opportunities for greater cost-effectiveness are identified. In addition, the results are compared with economic performances of conventional grid electricity generation. Benefits as well as losses are then determined. 
The life cycle cost can be broken down into the following categories:

(1) Production of PV modules

(2) Production of Inverters

(3) Provision of BOS equipment

(4) Installation labour

(5) Installer margin and overhead

(6) Contingency

(7) Permitting

(8) Engineering

(9) Grid interconnection

As defined in environmental LCA, the functional unit adopted in LCC is also $1 \mathrm{kWh}$ of solar PV electricity.

Levelized Cost of Electricity (LCOE) is used to calculate the life cycle cost of every $1 \mathrm{kWh}$ of electricity generated by UQ Solar. It is equal to the net present value of the total lifetime system cost when assigned to every unit of electricity produced by that system [31]. When the LCOE of UQ Solar falls at or below the cost of purchasing electricity from the grid, the point of "grid parity" is reached and the studied PV system becomes economically competitive.

Some assumptions are given:

(1) If the effect of inflation is taken into account, the "nominal" discount rate is $10.29 \% / y e a r$. On the contrary, the "real" discount rate is 7.6\%/year [21];

(2) Inflation rate is $2.5 \%$ year [21];

(3) Escalation rate is essentially the same as the inflation rate;

(4) $10 \%$ of the total installed cost is assumed to be the salvage value;

(5) The base date of this project is 1 June 2010, the service date is 1 June 2011, and the study period is 30 years;

(6) The results of this study are independent of government subsidies (e.g., renewable energy certificates, rebates) and special feed in tariffs arrangements, because the inclusion of incentive is not consistent with the strict definition of LCOE [23];

(7) DC to AC ratio is set to be 1.1, and interconnection derate is 0.97 in total;

(8) The utility rate is going to increase $1.82 \%$ /year given no carbon tax is considered [21];

(9) Loan rate is $7.78 \%$ /year [21];

(10)Federal income tax is $30 \%$ [32];

(11) Contingency is assumed to be $5 \%$.

\subsubsection{Life Cycle Inventory Analysis}

Main input values are summarized in Table S5. Defaulted values, zero values and automatically calculated values are not included.

\subsubsection{Life Cycle Impact Assessment}

The values of the main metrics are demonstrated in Table 1. From this table, it is clear to see LCOE of UQ Solar is 27.19 cents $/ \mathrm{kWh}$ taking the inflation rate into consideration. If removing the effect of 
inflation, the LCOE becomes 21.53 cents/ $\mathrm{kWh}$. In addition, the electricity cost per year is reduced with UQ Solar installation, which means UQ Solar can significantly reduce the amount of electricity that needed to be purchased from the utility grid previously by $23.21 \%$.

Table 1. Main Metric Values of System Advisor Model (SAM) Simulation.

\begin{tabular}{lc}
\hline \multicolumn{1}{c}{ Metric } & Value \\
\hline Annual Energy & $1771,513 \mathrm{kWh}$ \\
LCOE Nominal & $27.19 \phi / \mathrm{kWh}$ \\
LCOE Real & $21.53 \phi / \mathrm{kWh}$ \\
Electricity cost without system & $\$ 1397,169.13 /$ year \\
Electricity cost with system & $\$ 1072,829.13 /$ year \\
Net savings with system & $\$ 324,348.28 /$ year \\
Net present value $(\$)$ & $-\$ 1,304,143.13$ \\
Payback (years) & 13.6769 years \\
Capacity Factor & $16.84 \%$ \\
First year kWhac/kWdc & 1476 \\
System performance factor $(\%)$ & 0.83 \\
Total Land Area & $2.10 \mathrm{acres}$ \\
\hline
\end{tabular}

Net Present Value (NPV) is the sum of discounted future cash flows, both costs and revenues.

From Table 1, it is observed the NPV of UQ Solar is negative, which means the discounted lifetime revenues are less than discounted lifetime costs. In other words, UQ Solar is on its own not economically feasible. It is possible that NPV can become positive, if the utility electricity rate becomes higher or increases more significantly. If incentives or carbon taxes are taken into account, the NPV can possibly become positive as well. In this simulation, neither incentives nor grants are included in order to comply with the strict definition of LCOE. However, in actual case, the Queensland government provided 1.5 million Australian dollars to support this project, which suddenly turns the NPV into a positive value.

The payback (PB) period measures how long it takes for a project to recover the initial investment costs. It is a useful technique to weigh the additional capital costs against the time it takes for these costs to be recovered through savings or income during the operational period [33]. SAM calculates the payback period using non-discounted cash flow values [34].

Table 1 tells the PB for UQ Solar is 13.68 years, which indicates UQ Solar will recover its initial investment costs in about 14 years.

Apart from the metric table, there are some graphical presentations of this assessment. Figure 4 shows the after tax cash flow. It also proves NPV is negative in this case, and the final year revenue increases dramatically because salvage value is added. In terms of cost breakdown, Figure 5 shows that PV modules incur most of the costs, and the second and third biggest contributors are related to electric installation and inverters production, respectively.

In addition to various results mentioned above, SAM is so powerful that it can generate a financial report automatically, and this report is attached as appendix material. 


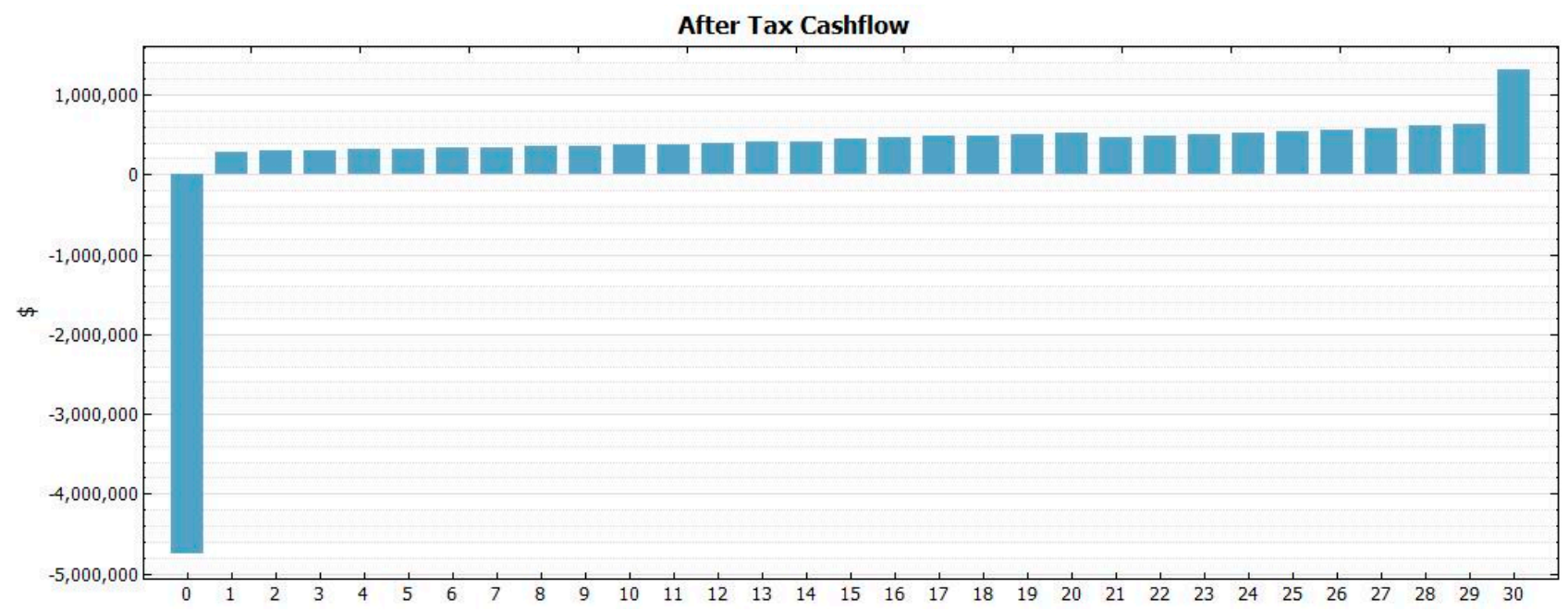

Figure 4. UQ Solar - after tax cash flow.

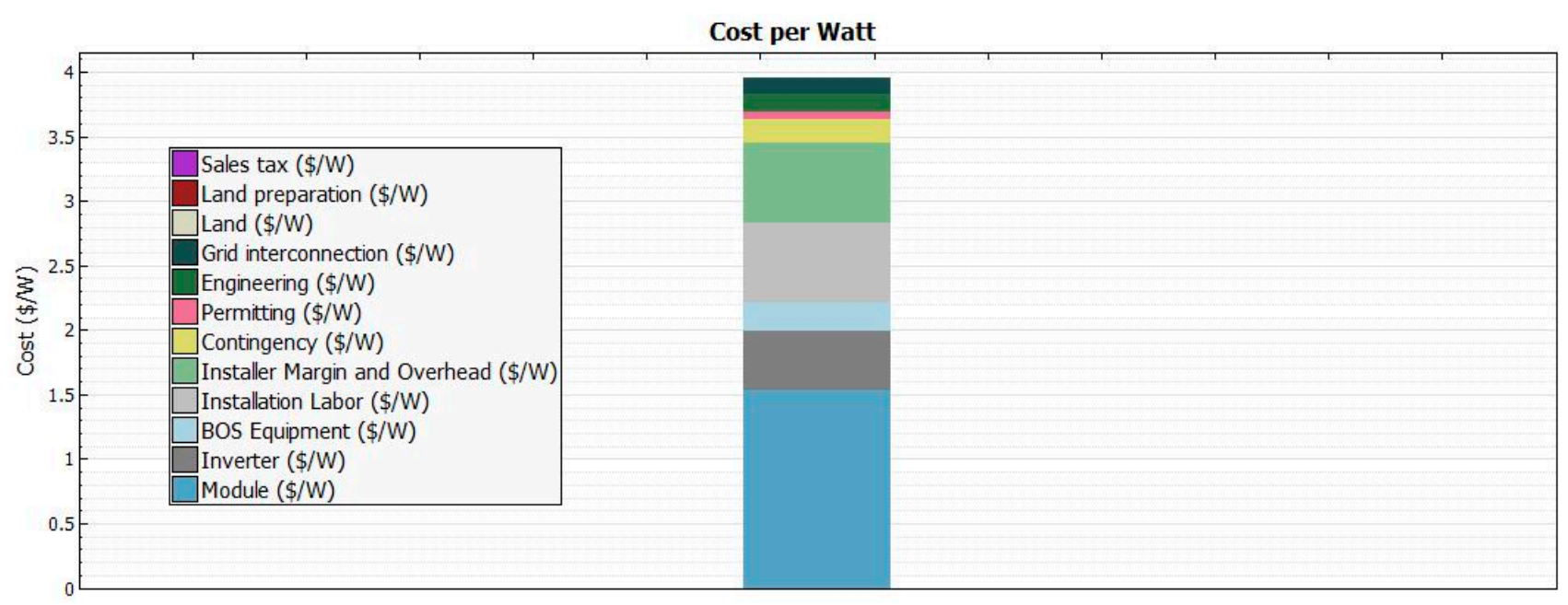

Figure 5. UQ Solar- cost per watt.

\subsubsection{Interpretation}

According to the results calculated by SAM, the real LCOE of UQ Solar is 21.53 cents $/ \mathrm{kWh}$, and the nominal LCOE is 27.19 cents/kWh. Cost per watt is about 3.96 dollars.

(1) When comparing these values with the utility electricity rates paid by UQ to the Queensland electricity network provider, which is about 12.5 cents/kWh [17], UQ Solar is not an attractive investment at present if there are not any incentives, grants, or carbon taxes.

(2) When comparing real LCOE value with Queensland average residential time of use (TOU) tariff, which is about 22.07 cents/kWh [35], grid parity has been reached. Especially when feed-in-tariff and renewable energy certificates apply, PV installation seems more appealing.

(3) When comparing these values with LCOE offset electricity, which is about 28 cents/kWh in 2012 [21], it can be concluded UQ Solar is more or less economically competitive.

(4) When considering projections of these two systems, it is reasonable to predict PV installation will become more and more beneficial because LCOE of PV will be continually decreasing while LCOE of grid electricity will be generally increasing. 
In order to verify the conclusions of this study, the results are compared with the results obtained from other studies.

(1) The LCOE is 26.5 cents/kWh for a $100 \mathrm{~kW}$ commercial polycrystalline PV installation in Sydney in 2011 [21], which is very similar to the result of this study.

(2) From the UQ Solar website, it is known the initial cost of the studied system is 4.746 million, the cost per watt is approximately 3.955 dollars, and the payback period for this project is 10-12 years [17]. These results are also similar to the results of this study. While the UQ Solar website considers government grants, this study does not.

This study mainly makes use of SAM to simulate the UQ Solar project. Since SAM is basically accommodated to US conditions, this simulation cannot be very precise. In addition, many assumptions are made due to the lack of specific data. Therefore, the deliverables may not be reliable. Uncertainty analysis should be conducted to clarify this problem.

\subsection{UQ Solar $S-L C A$}

\subsubsection{Goal and Scope Definition}

The main goal is to qualitatively assess the social performances of UQ Solar from different stakeholders' perspectives. Main social impacts are analyzed and critical interpretations are delivered.

The boundary of this intended system is delimited at an organizational level, starting from the organizations producing PV modules to the organizations dealing with end-of-life treatment. In each stage of the life cycle, different stakeholders/organizations are involved, and the assessment is made against different stakeholders' interests in each stage (Figure 6).

$>$ Stakeholders

Major stakeholders involved and their respective roles are marked in Figure 6.

$>$ Subcategories

Subcategories are assigned to several stakeholders who potentially have significant impacts. These subcategories are selected against each stakeholder's main roles and interests, and they can be found in the life cycle inventory analysis and life cycle impact assessment.

$>$ Limitation

Due to very limited data availability, the complex social assessment has to be a generic, qualitative and subjective one. Only main stakeholders are selected, and the information collected is neither completely unbiased nor comprehensively inclusive. Therefore, all the conclusions need to be read with caution. However, it can be considered as a good starting point to conduct more profound and advanced social assessment. 


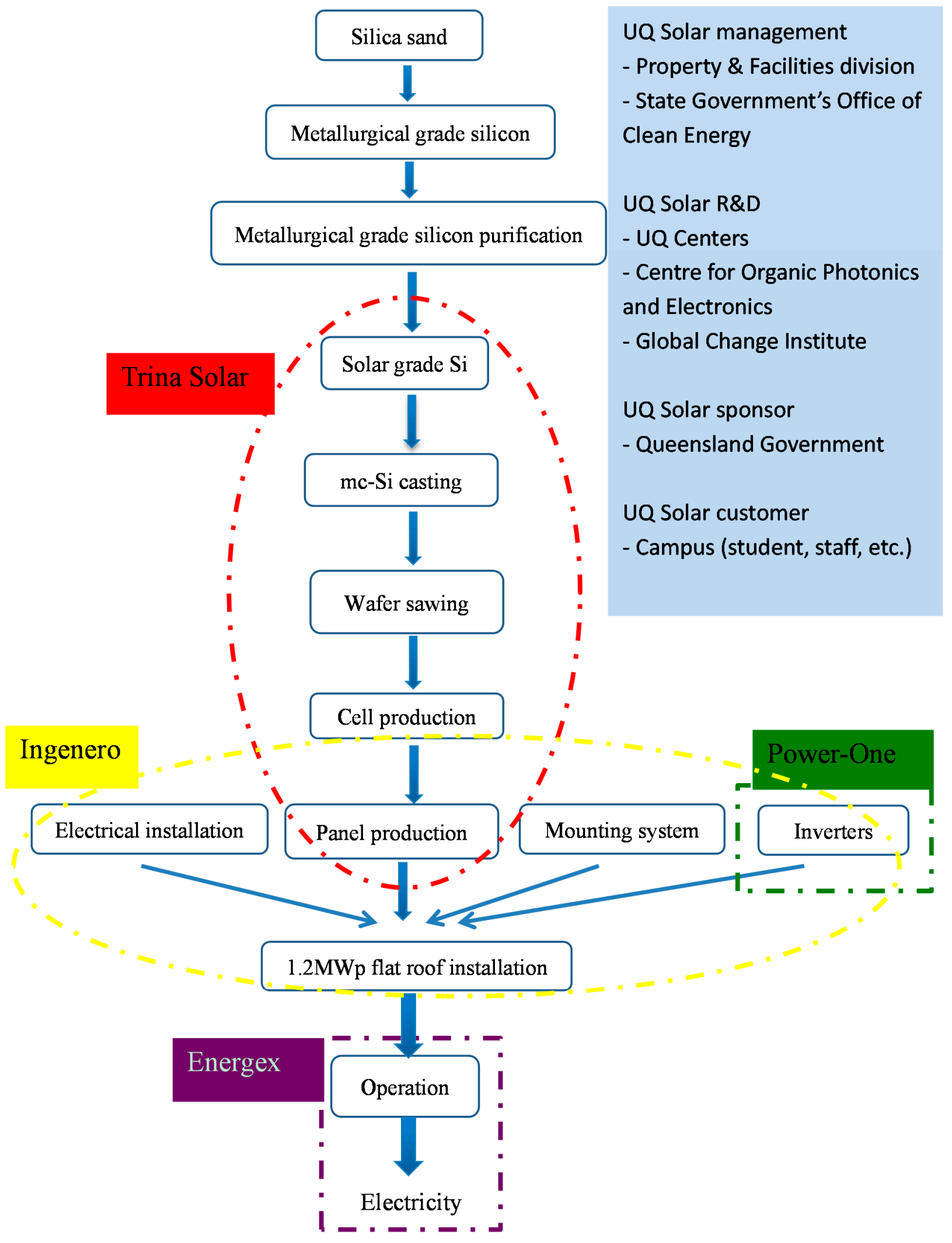

Figure 6. S-LCA system boundary and principal stakeholders.

\subsubsection{Life Cycle Inventory Analysis}

Information is collected for every subcategory to build up the inventory analysis. 


\section{$>$ Trina Solar}

\section{- Business ethics}

Trina Solar has established the "Code of Business Conduct and Ethics", in which it highlights anti-corruption, integrity and compliance, reporting mechanism, and high business ethical standards with suppliers and partners [36].

- Supplier relationships

In order to improve the social responsibility performance of suppliers, Trina Solar exerts some influence on them. Trina Solar carries out risk assessments annually to list key suppliers who comply with its requirements on sustainable development. Trina Solar has implemented Supplier CSR Management Procedure. Key suppliers are required to sign a commitment letter in order to strengthen communication and cooperation between different suppliers. In 2012, 18 key suppliers had been through EHS/CSR audits, among which 11 are conditionally accepted and three are disqualified [36].

- Care for employees

Following laws and regulations, employees' rights are protected: no forced labor or child labor; men and women are equally paid; no discrimination incidents; various insurances, funds and benefits are guaranteed [36]. However, in fact, it is recognized the enforcement of law in China is not very strict, and the inspection can be very superficial.

In 2012, the amount of employees reached $12,000,67.3 \%$ of which had joined a labor union. Female employee ratio is $36.5 \%$, and $100 \%$ of employees' salary is higher than the stipulated minimum. Total recordable rate is 0.56 per million working hour. There is no work-related fatality, and the average training hours is $33 \mathrm{~h}$ per employee per year. US $\$ 4.568$ million had been invested in safety and occupational health management [36].

- Health and safety

Trina Solar has implemented both an Environmental Health and Safety policy and Product Stewardship policy to ensure the commitment to designing and manufacturing solar photovoltaic modules with overall lower impacts on the environment, and employees' health, safety and well-being. In November 2012, Trina Solar had passed Occupational Health and Safety management system (OHSAS 18001) verification [36].

However, it is known that during the manufacturing and disposal phase, many toxic and hazardous metals and chemicals can be generated to harm workers who work around them. For example, sawing c-Si wafers may generate silicon particulate matter that can pose inhalation problems [37]. Especially, in China, the problems would get more serious as environmental regulatory enforcement is low. Therefore, it is not indubitable to conclude Trina Solar has no problems in dealing with health and safety problems.

- Contribution to society

Apart from doing business, Trina Solar contributes to the society development in many ways. Trina Solar established an international school to support education, and it donated solar PV modules to universities for demonstration and education, etc. [36]. 
- End of life management

Trina Solar encourages Extended Producer Responsibility (EPR), and it collects end-of-life PV modules sold in Europe through PV Cycle initiative [38]. In Europe, the end-of life or defective PV modules are recycled at facilities with certified environmental management systems.

By and large, Trina Solar is a social responsible company and it is ranked No. 1 for its environmental and social performances in the 2012 Solar Scorecard among 40 companies globally [38].

\section{UQ R\&D}

- Contribution to technology development

The establishment of UQ Solar has facilitated the research activities in UQ regarding photovoltaic development.

UQ Center proactively carries out many researches on renewable energy system, and UQ Solar can provide the opportunities for many efficiency improvement experiments. Centre for Organic Photonics and Electronics are developing emerging PV technologies. Although UQ Solar does not utilize any new technologies, it is still a good establishment for comparative research, and emerging technologies can also be added to this establishment for pilot-scale research. The Global Change Institute is conducting researches that are, in particular, using UQ Solar. They are working on the storage devices, the concentrated PV installation and the shading effects [17].

- Contribution to research collaboration

As the largest flat panel installation in Australia, UQ Solar can be regarded as a demonstration project, which may attract many researchers in other universities, institutes, and industries to work together to improve the overall performances of PV system. Not only can scholars in science and engineering fields participate, experts in social science and economics are also encouraged to make contributions.

Queensland government

- Consistency with Federal government

Australia has Federal, State and local governments, and they all have different priorities, jurisdictions, incentives and motivations. In order to respond to climate change, the Federal government has set several greenhouse gas emission reduction targets for different periods, and the transition to more renewable energy deployment is taking place. However, current policies still favor more mature and cheaper technologies such as hydro and wind, which have little thing to do with solar photovoltaic. Some non-renewable but "greener" fossil fuels (e.g., natural gas, coal seam gas) are considered as critical contributors to emission reduction. In addition, some emission intensive and trade-exposed industries (steel, alumina, coal fired power stations, etc.) are privileged, subsidized and protected from participating in renewable energy targets and carbon pricing in order to balance social concerns regarding jobs and competitiveness. More seriously, many practical barriers exist in implementing renewable energy policies, such as lengthy and complicated permitting procedures, costly and non-transparent grid connection, uncertainty of returns, etc. In summary, all the above-mentioned factors undermine the potential environmental, economic, and social contributions of emerging renewable energy industries, and renewables are actually not competing on an equal playing field [39]. 
Globally speaking, Queenslanders emit the highest amount of greenhouse gases, and Queensland is a major exporter of coal and gas [40]. However, very few down to earth initiatives have been implemented to tackle this urgent problem. The Queensland government has set many strong renewable energy targets, and it has also outlined some funding strategies. However, no sufficient details are proposed to address the barriers existing in renewable energy development. On the contrary, large sums of subsidies are still provided to support conventional fossil fuel industry, and some policies still promote rapid expansion of coal/gas mining to increase export sales. With regard to solar photovoltaic development, the Queensland government did exceptionally well in promoting the uptake of residential solar PV systems, however, the major challenges still lay in deploying large-scale PV installations [41]. After the change of government in the Queensland election in March 2012, almost all renewable energy funding was cancelled, which substantially hinders the deployment of renewables as they largely rely on regulatory intervention to be commercially viable [39].

As far as it is known, the Queensland government is consistent with the Federal government in dealing with renewable energy transition, however, in discouraging ways.

- Commitment to carbon emission reduction

With particular respect to UQ Solar, the Queensland government has provided AU $\$ 1.5$ million to support this project, which, to some extent, indicates its intention to reduce carbon emissions. However, such a small contribution is not convincing enough to express its commitment.

- Social influences

UQ Solar is not very helpful to government to exert influences on society to use more renewable energy. It is more academic-oriented, and it is a big challenge to make the project widely known.

$>$ Electricity distribution network

- Compatibility and stability

In Australia, the majority of electricity is firstly generated by large centralized generators, and then it is transmitted at high voltage through transmission networks, after which distribution networks take over at low voltage before reaching end consumers [39]. This centralized system is both cheap and efficient, but it also faces many challenges nowadays due to changing demand patterns and deteriorating environmental problems. The prevailing "top-down" structure needs to be transformed to a "bottom-up" structure as consumers may have a number of alternatives to choose from [42].

However, for UQ Solar only, the electricity distribution network is readily available so that no extra efforts or costs need to be paid to expand the current network.

- Profitability

For electricity network provider Energex, the establishment of UQ Solar can be both good and bad. When peak demand cannot be met, UQ Solar can provide a reliable energy backup. However, when UQ Solar provides too much electricity, it will reduce electricity use and electricity utility revenues. 
Customers (local community)

- Health and safety

During the operation of UQ Solar, it is not likely to generate any toxic/hazardous materials or noises; therefore, it is quite a safe renewable technology during its operation. However, if some unexpected accidents happen, exposure to toxic materials can be very harmful.

- Feedback mechanism

There is no extensive feedback mechanism available to students and local communities, as they are not much affected by UQ Solar. However, for the Property \& Facility Division of UQ, a feedback mechanism is available, because there should be some feedback on how good the system runs, what problems it brings and how to address them.

- Transparency

It is quite a transparent project because a data acquisition system (DAS) has been installed on a data display screen. Real-time output of the PV system can be displayed.

- Awareness and training

For general students and local communities, UQ Solar is not well exploited for awareness enhancement and training.

- Community engagement

The community is not actively engaged, as they are not directly/seriously affected.

- Local employment

The solar energy sector has the potential to provide hundreds of thousands of jobs in fields of manufacturing, construction, installation, and maintenance. However, this environmentally sustainable industry may end up with unsustainable jobs, which keep workers and their families in poverty [43]. Besides, the creation of jobs in solar industry indicates fewer jobs are needed in the conventional electricity industry.

\subsubsection{Life Cycle Impact Assessment}

In the life cycle impact assessment, a nine-color scale is employed to qualitatively assess the social impacts of UQ Solar based on the information gathered from inventory analysis (Figure 7). 


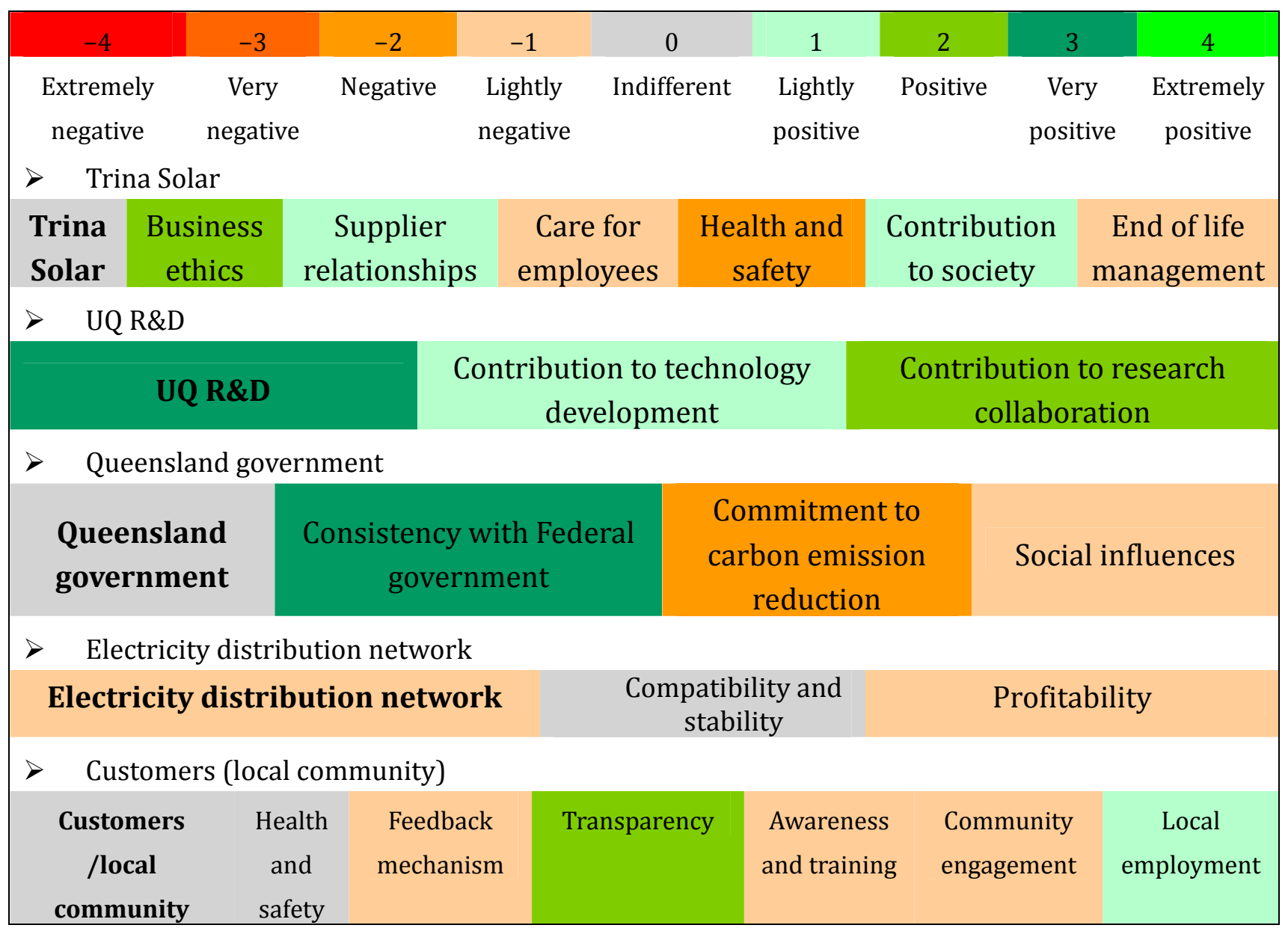

Figure 7. Nine-color scale qualitative assessment for the S-LCA of UQ Solar.

\subsubsection{Interpretation}

From the impact assessment, the overall score of Trina Solar is indifferent. To be more specific, Trina Solar performs better in business ethics, supplier relationships, and contribution to the society, while there are some problems in caring for employees, health and safety, and end of life treatment. The main challenges underlying PV modules production are toxic/hazardous materials emissions. In order to reduce and eventually eliminate this problem, several stakeholders should work together.

Solar PV manufacturers should be responsible for the lifetime impacts of PV modules through Extended Producer Responsibility (EPR). Starting from the design stage, PV manufacturers should make sure PV modules as well as components can be easily and safely recycled; during production process, manufacturers should protect workers and the environment from toxic exposure, and they should also monitor supply chains to ensure safe and just practices; during operation stage, manufacturers are expected to protect community health and safety by informing of the potential risks in using solar modules; during end-of-life treatment, manufacturers should establish effective take-back policies for solar modules. Federal and State policymakers should also provide corresponding policies and legislations to support/enforce these implementations. In addition, consumers can make big differences with the power of the market [37].

UQ Solar is a very good establishment for R\&D activities and the overall result is quite positive. In order to maximize the efficacy of UQ Solar, more collaboration with outside stakeholders is encouraged. 
The Queensland government is indifferent to the overall result of the project because, although its policies and initiatives are consistent with the Federal government's, both do not attach importance to renewable energy deployment. There are many challenges in exploiting renewable resources, including immature technologies, higher costs, institutional inexperience, incompatible with exiting transmission and distribution networks, etc. [39]. Government should introduce carbon pricing to internalize environmental costs that are associated with conventional electricity generation, and more importantly, the costs should be borne by the industry itself rather than taxpayers. Non-renewable but "greener" fossil fuels should be excluded when considering carbon emission reduction measures. In addition, free credits or direct subsidies for emissions intensive and trade-exposed industries should be phased out. Administrative and regulatory issues regarding renewable energy deployment should be streamlined to save on the costs of deployment.

In the case of UQ Solar, the electricity distribution network is slightly negatively affected. Assuming a larger-scale PV installation in remote area, which has not been integrated into the existing distribution network, the negative impacts will become more significant, because higher grid connection costs will ensue and the electricity utility revenue will decrease. In order to alleviate the negative impacts, government should invest more in building up/expanding electricity infrastructure.

UQ Solar has positive impacts on transparency and local employment, but it does not make many differences in terms of awareness enhancement and community engagement. It should be noted that social acceptance and willingness are indispensible for solar photovoltaic development. As customers tend to rely on technologies they are more familiar with, a lot of effort should be taken to enhance public awareness and training of solar photovoltaic technology.

\subsection{UQ Solar Integrated LCSA}

Based on the life cycle assessments on all three pillars of sustainability, we can make conclusions about the sustainability performances of UQ Solar. The overall results suggest UQ Solar performs well in environmental aspects, and it is economically feasible with grants provided by the Queensland government. However, its performance in social aspects is not as good as expected, although no serious adverse impacts are detected. This study assumes each dimension weighs equally, and if one stands for worst performance and five stands for the best performance, the overall sustainability performance can be illustrated using Figure 8.

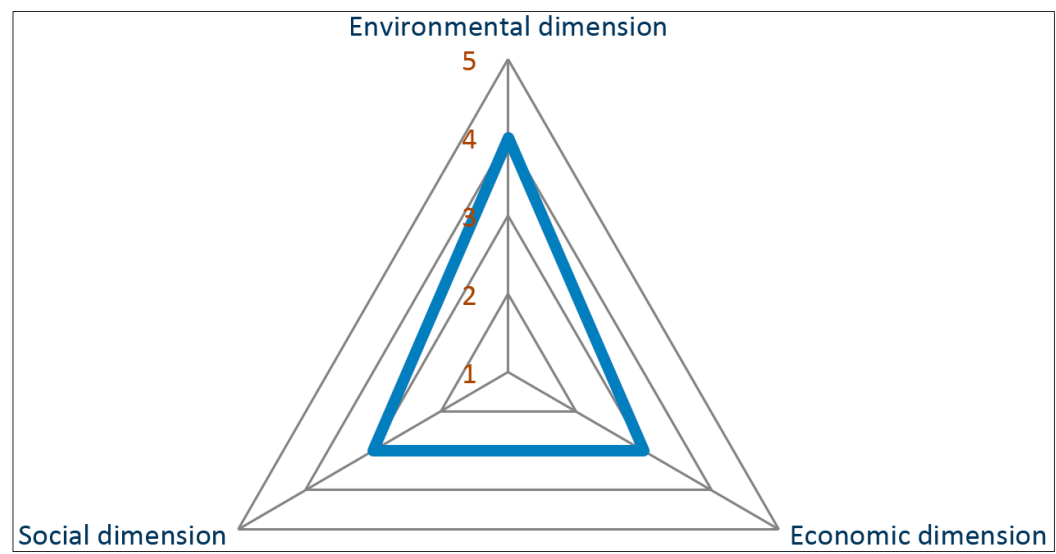

Figure 8. UQ Solar Sustainability Dashboard. 


\section{Discussion}

\subsection{Problem Identification}

In this section, problems are identified according to the three dimensions separately.

\subsubsection{Environmental Dimension}

In the environmental aspects, UQ Solar performances quite well, except for emissions of several criteria air pollutants (As, $\mathrm{Cd}, \mathrm{Cr}, \mathrm{Pb}$ and $\mathrm{C}_{6} \mathrm{H}_{6}$ ). During the life cycle of UQ Solar, $\mathrm{PV}$ modules' production contributes most to environmental impacts, followed by the mounting structure and electrical installation.

\subsubsection{Economic Dimension}

The LCOE of UQ Solar is more or less the same as LCOE of offset electricity, although this value is far higher than the utility rate currently paid by UQ. However, the NPV of UQ Solar is negative without considering Government grants, which makes it economically infeasible. PV modules production takes up the largest share of the cost.

\subsubsection{Social Dimension}

Generally speaking, UQ Solar does not generate very serious adverse social impacts. However, it does not fulfill its expected social functions fully. Not many people are aware of this project, thus no educational or training purposes are reached. The most serious potential impact could be the health and safety problems caused by modules' production and end-of-life treatment. Besides, governments on different levels are not truly supportive of deploying large-scale renewable energy installations, and the lack of necessary infrastructure facilities is another big challenge.

\subsection{Recommendations}

In this section, recommendations are proposed according to the three dimensions separately.

\subsubsection{Environmental Dimension}

Since PV modules' production contributes most to environmental impacts, it is the manufacturer's responsibility to address this problem.

Solar PV manufacturers should be responsible for the lifetime impacts of PV modules starting from design stage to the end-of-life treatment. PV manufacturers should work together with research institutes to find out more material efficient and less energy intensive production processes; Any toxic or risky materials should be reduced and even eliminated from the manufacturing process; Any new materials or components should be carefully tested in order to know their toxicity and safety before using them; Manufacturers should protect workers and the environment from toxic exposure through strict management systems; Manufacturers should also monitor supply chains to ensure safe and just practices; During operation stage, manufacturers are expected to protect community health and safety by informing of the potential risks in using solar modules; During end-of-life treatment, manufacturers should establish 
effective take-back policies for solar modules to recycle them easily and safely. Federal and State policymakers should also enforce corresponding policies and legislations to support these implementations.

\subsubsection{Economic Dimension}

At present, government support (incentives, subsidies, grants) is indispensible for large PV installations to be economically viable. In order to make PV systems more economically competitive, conventional utility electricity rates should be increased more significantly. In addition, consumers can exert much influence on the economic performances of PV installation through the power of the market.

\subsubsection{Social Dimension}

As a matter of fact, the problems existing in the social dimension are closely related to environmental problems and economic problems. More efficient and responsible production can effectively ease the impacts on health and safety. Government should truly support the deployment of large-scale PV installation by providing more funds and infrastructure. Subsidies provided for fossil fuel power stations should be phased out, and more awareness and training activities should be organized to promote social acceptance.

\section{Conclusions and Prospects}

\subsection{Key Messages}

Australia possesses the highest average solar radiation of any continent in the world, and the annual solar radiation is approximately 10,000 times more than Australia's annual energy consumption. However, solar energy so far has not been largely developed. This study intends to investigate the sustainability of current solar PV installations in Australia on the project level in order to know why solar photovoltaic is not favored, what the problems are and how to possibly solve them.

Life cycle sustainability assessment is conducted on a specific case called UQ Solar, and the basic conclusion is that PV installations can be sustainable in Australia, but several environmental, economic, and social problems need to be addressed first. PV manufacturers should be assigned more responsibility in reducing and, eventually, eliminating toxic/hazardous materials used in PV modules production; End-of-life treatment should be taken good care of by manufacturers to make sure solar modules/components/materials can be reused/recycled/recovered; Government should truly support the deployment of large-scale PV installation by providing more incentives/funds/infrastructures; Substantial subsidies for fossil fuel power stations should be phased out; More awareness and training activities should be organized to promote the social acceptance of solar PV installations.

\subsection{Limitations}

Due to time constraints and budget restrictions, this study has many limitations that need to be improved in future studies. 
(1) As the main objectives of this study are to know whether current solar photovoltaic deployment is sustainable in Australia and how to make large-scale installation more sustainable in the future, it is not sufficient to assess just one case on the project level.

(2) Life cycle sustainability assessment is such a complex topic that it is not sufficient to just assess three dimensions of sustainability separately.

(3) UQ Solar is selected in this study because it is the largest flat roof PV installation in Australia and it is easily accessed. However, some social and economic problems cannot be properly examined in an academic-oriented establishment.

(4) The limitations mentioned in each section of the assessment emphasize the limitations of data quality in this study. Not all data are case specific, and the interpretation of results, to a large extent, depends on the assumptions made.

(5) When discussing a complex problem regarding sustainability, expert review and stakeholder participation can be very helpful, sometimes necessary, to grasp a comprehensive picture of this problem.

\subsection{Prospects}

Although there are many limitations of this study, it is still a good starting point for many further studies.

(1) With the aim of achieving sustainable large-scale PV installation in Australia, additional macro-level or landscape level systems need to be investigated to complete multi-level perspective analysis. It is helpful to employ adaptive and dynamic mechanisms.

(2) Life cycle sustainability assessment is such a complex topic that more integrated frameworks should be adopted. It is recommended to take system interrelationships as well as dynamics into account.

(3) In order to know what the social and economic problems really are, cases selected for study should cover different technologies adopted in different sizes of systems at different locations. The more representative the cases are, the more convincing the study is.

(4) Further studies should concentrate on case-specific data gathering. At present, most of the data collected are based on European conditions, so it is crucial to improve Australian life cycle databases to find out problems that are urgently taking place in Australia. Sensitivity and uncertainty analysis should be conducted to make the results more reliable.

(5) If possible, experts and stakeholders should actively take part in sustainability assessment. Their opinions should be considered during the whole life cycle assessment and adjustments should be made accordingly.

\section{Acknowledgments}

We are grateful to some support from the UQ Centre and Global Change Institute of the University of Queensland. We also acknowledge the efforts of the reviewers. 


\section{Author Contributions}

Man Yu and Anthony Halog conceived and designed this study together. Man Yu collected and analyzed the data, and Anthony Halog reviewed and improved the analysis. All authors read and approved the final manuscript.

\section{Appendix}

Assumptions of UQ Solar LCA

In order to achieve the goals, several assumptions are made based on literature review and mathematical inferences.

(1) Delivery of various system components via road transport, including the transport of construction workers, is assumed to be $100 \mathrm{kM} \mathrm{[27];}$

(2) The existing database only has data on the inverter with a capacity of $2500 \mathrm{~W}$, while in fact $5000 \mathrm{~W}$ and $12.5 \mathrm{~kW}$ inverters are used, therefore the data are correspondingly scaled using mass ratio 1.4 (2.3) [44] and energy ratio 2 (5) for $5000 \mathrm{~W}(12.5 \mathrm{~kW})$ inverters;

(3) For electric installation, most of material use can be assumed to be proportional to the installed capacity;

(4) It is known 1800 MWh of electricity is generated per year for 1.22 MWp PV installation [17], so it is assumed $1770 \mathrm{MWh}$ of electricity, in proportion, is generated per year for $1.2 \mathrm{MWp}$ installation;

(5) In database, the data is made for $3 \mathrm{kWp}$ installation [27], while in fact the system is $1.2 \mathrm{MWp}$. So, every value is multiplied by 400 to fit in the studied system;

(6) The whole defined PV system is uniformly simplified as flat roof installation;

(7) The electricity supplied to UQ campus by conventional Queensland electricity grid does not have significant transmission-distribution losses;

(8) All casted mc-Si is produced from solar-grade silicon; neither electronic grade silicon nor upgraded MG silicon is used.

Table A1. UQ Solar life cycle emissions of criteria air pollutants and greenhouse gases.

\begin{tabular}{lccccccc}
\hline & Unit & $\begin{array}{c}\text { PV } \\
\text { Modules }\end{array}$ & $\begin{array}{c}\text { Mounting } \\
\text { System }\end{array}$ & $\begin{array}{c}\text { Electric } \\
\text { Installation }\end{array}$ & Inverter & Transportation & Total \\
\hline Air Pollutants & & & & & & & \\
Carbon monoxide $(\mathrm{CO})$ & $\mathrm{kg}$ & 1872.5 & 2200 & 108 & 188.75 & 394.28 & 4763.62 \\
Hydrocarbons $(\mathrm{HC})$ & $\mathrm{kg}$ & 19.70 & 3.23 & 0.67 & 1.18 & 1.00 & 25.78 \\
Lead $(\mathrm{Pb})$ & $\mathrm{kg}$ & 8.99 & 0.163 & 2.95 & 1.33 & 0.03 & 13.46 \\
Nitrogen Oxides $\left(\mathrm{NO}_{\mathrm{x}}\right)$ & $\mathrm{kg}$ & 9190 & 514 & 171 & 272.4 & 432 & $10,581.2$ \\
Particulate Matter $\left(\mathrm{PM}_{10}\right)$ & $\mathrm{kg}$ & 1922.94 & 272 & 126.24 & 101.24 & 25.28 & 2447.77 \\
Sulfur Oxides $\left(\mathrm{SO}_{\mathrm{x}}\right)$ & $\mathrm{kg}$ & 24.8 & 0 & 0.901 & 57.37 & 0 & 84.33 \\
\hline Greenhouse gases & & & & & & & \\
Carbon dioxide $\left(\mathrm{CO}_{2}\right)$ & $\mathrm{kg}$ & $2,690,000$ & 285,000 & 44,700 & 76,610 & 59,180 & $3,155,877$ \\
Methane $\left(\mathrm{CH}_{4}\right)$ & $\mathrm{kg}$ & $15,441.4$ & 599 & 122.246 & 147.699 & 69.54 & $16,380.32$ \\
\hline
\end{tabular}


Table A2. Air pollution comparison between two electricity generation systems.

\begin{tabular}{clccc}
\hline & & PV System (g/kWh) & Conventional Grid (g/kWh) & Net Emission (g/kWh) \\
\hline \multirow{4}{*}{ Metals } & Arsenic (As) & $4.28 \times 10^{-5}$ & $1.41 \times 10^{-5}$ & $-2.87 \times 10^{-5}$ \\
& Cadmium (Cd) & $1.34 \times 10^{-5}$ & $3.42 \times 10^{-6}$ & $-1.00 \times 10^{-5}$ \\
& Chromium (Cr) & $5.15 \times 10^{-5}$ & $2.84 \times 10^{-5}$ & $-2.30 \times 10^{-5}$ \\
& Mercury (Hg) & $2.34 \times 10^{-6}$ & $5.54 \times 10^{-6}$ & $3.20 \times 10^{-6}$ \\
\hline \multirow{4}{*}{ Criteria Air } & Lead (Pb) & $2.53 \times 10^{-4}$ & $2.79 \times 10^{-5}$ & $-2.26 \times 10^{-4}$ \\
Pollutants & Carbon Monoxide (CO) & $8.96 \times 10^{-2}$ & $7.20 \times 10^{-1}$ & $6.30 \times 10^{-1}$ \\
& Particulate Matter (PM10) & $4.61 \times 10^{-2}$ & $1.39 \times 10^{-1}$ & $9.32 \times 10^{-2}$ \\
& Nitrogen Oxides $\left(\mathrm{NO}_{\mathbf{x}}\right)$ & $1.99 \times 10^{-1}$ & 3.67 & 3.47 \\
\hline \multirow{2}{*}{ Greenhouse } & Culfur Oxides $\left(\mathrm{SO}_{\mathbf{x}}\right)$ & $1.57 \times 10^{-3}$ & 2.73 & 2.73 \\
gases & Carbon Dioxide $\left(\mathrm{CO}_{2}\right)$ & $5.94 \times 10^{1}$ & $8.64 \times 10^{2}$ & $8.05 \times 10^{2}$ \\
\hline Air Toxics & Bethane $\left(\mathrm{CH}_{4}\right)$ & $3.08 \times 10^{-1}$ & $7.92 \times 10^{-1}$ & $4.84 \times 10^{-1}$ \\
\hline
\end{tabular}

Table A3. Life cycle impact assessment of UQ Solar (CML 2 baseline 2000).

\begin{tabular}{|c|c|c|c|c|c|c|c|}
\hline Impact Category & Unit & Inverter & $\begin{array}{c}\text { Electric } \\
\text { Installation }\end{array}$ & $\begin{array}{l}\text { Mounting } \\
\text { System }\end{array}$ & PV Module & Transportation & Total \\
\hline Abiotic depletion & $\mathrm{kg} \mathrm{Sb}$ eq & 507.2442 & 349.7557 & 2116.7385 & $20,024.71$ & 416.2695 & $23,414.71$ \\
\hline Acidification & $\mathrm{kg} \mathrm{SO}_{2} \mathrm{eq}$ & 736.0431 & 926.10171 & 1305.7183 & $27,130.96$ & 341.8155 & $30,440.64$ \\
\hline Eutrophication & $\mathrm{kg} \mathrm{PO}_{4} \mathrm{eq}$ & 710.8017 & 1031.4202 & 476.21218 & 3597.214 & 81.6106 & 5897.259 \\
\hline $\begin{array}{c}\text { Global warming } \\
\text { (GWP100) }\end{array}$ & $\mathrm{kg} \mathrm{CO}_{2}$ eq & $82,154.04$ & $48,457.16$ & 338080.4 & $3,153,394$ & $61,980.09$ & $3,684,066$ \\
\hline $\begin{array}{c}\text { Ozone layer depletion } \\
\text { (ODP) }\end{array}$ & $\mathrm{Kg} \mathrm{CFC}-11 \mathrm{eq}$ & 0.005396 & 0.0013523 & 0.0162321 & 0.295842 & 0.00905 & 0.327872 \\
\hline Human toxicity & $\mathrm{kg} 1,4-\mathrm{DB}$ eq & $500,004.4$ & $935,956.42$ & $1,150,067.6$ & $1,643,401$ & $21,015.72$ & $4,250,445$ \\
\hline $\begin{array}{l}\text { Fresh water aquatic } \\
\text { ecotoxicity }\end{array}$ & kg 1,4-DB eq & $182,845.5$ & $5,690,261$ & $233,253.8$ & $705,574.5$ & 5944.029 & $6,817,879$ \\
\hline $\begin{array}{c}\text { Marine aquatic } \\
\text { ecotoxicity }\end{array}$ & $\mathrm{kg} 1,4-\mathrm{DB}$ eq & $4.72 \times 10^{8}$ & $1.84 \times 10^{9}$ & $326,874,804$ & $1.56 \times 10^{9}$ & $13,497,108$ & $4.22 \times 10^{9}$ \\
\hline Terrestrial ecotoxicity & $\mathrm{kg} \mathrm{1,4-DB} \mathrm{eq}$ & 1375.375 & 2331.5322 & 2896.7959 & $12,883.78$ & 123.399 & $19,610.89$ \\
\hline Photochemical oxidation & $\mathrm{kg} \mathrm{C}_{2} \mathrm{H}_{4} \mathrm{eq}$ & 63.3772 & 36.694604 & 109.93306 & 1099.181 & 21.09426 & 1330.28 \\
\hline
\end{tabular}

Table A4. Life cycle impact assessment comparison.

\begin{tabular}{lccc}
\hline \multicolumn{1}{c}{ Impact Category } & Unit & PV System (kg/kWh) & Conventional Grid (kg/kWh) \\
\hline Abiotic depletion & $\mathrm{kg} \mathrm{Sb} \mathrm{eq}_{\mathbf{k}}$ & 0.000441 & 0.000553 \\
Acidification & $\mathrm{kg} \mathrm{SO}_{2} \mathrm{eq}$ & 0.000573 & 0.005129 \\
Eutrophication & $\mathrm{kg} \mathrm{PO}_{4} \mathrm{eq}$ & 0.000111 & 0.000518 \\
Global warming (GWP100) & $\mathrm{kg} \mathrm{CO}$ eq & 0.069393 & 0.909119 \\
Ozone layer depletion (ODP) & $\mathrm{kg} \mathrm{CFC-11} \mathrm{eq}$ & $6.17 \times 10^{-9}$ & $5.31 \times 10^{-10}$ \\
Human toxicity & $\mathrm{kg} \mathrm{1,4-DB} \mathrm{eq}$ & 0.080053 & 0.29406 \\
Fresh water aquatic ecotox. & $\mathrm{kg} \mathrm{1,4-DB} \mathrm{eq}$ & 0.128401 & 0.247349 \\
Marine aquatic ecotoxicity & $\mathrm{kg} \mathrm{1,4-DB} \mathrm{eq}$ & 79.41658 & 800.2707 \\
Terrestrial ecotoxicity & $\mathrm{kg} \mathrm{1,4-DB} \mathrm{eq}$ & 0.000369 & 0.000413 \\
Photochemical oxidation & $\mathrm{kg} \mathrm{C} \mathrm{H}_{4}$ eq & $2.51 \times 10^{-5}$ & 0.000189 \\
\hline
\end{tabular}


Table A5. SAM main input values.

\begin{tabular}{|c|c|}
\hline Input Variable & Value \\
\hline Analysis Parameters/Analysis Period (years) & 30 \\
\hline Analysis Parameters/Federal Income Tax Rate (\%/year) & 30 \\
\hline Analysis Parameters/Inflation Rate (\%/year) & 2.5 \\
\hline $\begin{array}{l}\text { Analysis Parameters/Net Salvage Value } \\
(\% \text { of installed cost })\end{array}$ & 10 \\
\hline Analysis Parameters/Real Discount Rate (\%/year) & 7.6 \\
\hline Array/DC to $\mathrm{AC}$ ratio & 1.1 \\
\hline $\begin{array}{l}\text { CEC Performance Model with Module } \\
\text { Database/Array height }\end{array}$ & One story building height or lower \\
\hline $\begin{array}{l}\text { CEC Performance Model with Module } \\
\text { Database/Mounting standoff }\end{array}$ & Building integrated \\
\hline CEC Performance Model/Columns of modules in array & 10 \\
\hline CEC Performance Model/Gap Spacing (m) & 0.05 \\
\hline CEC Performance Model/Heat Transfer Dimensions & Module Dimensions \\
\hline CEC Performance Model/Material & Multi-c-Si \\
\hline CEC Performance Model/Module Area $\left(\mathrm{m}^{2}\right)$ & 1.618 \\
\hline CEC Performance Model/Module Name & $\begin{array}{l}\text { SAM/CEC Modules/Trina Solar } \\
\text { TSM-240PA05.38 }\end{array}$ \\
\hline CEC Performance Model/Module Width (m) & 0.992 \\
\hline CEC Performance Model/Mounting Configuration & Rack \\
\hline CEC Performance Model/Number of Cells & 60 \\
\hline CEC Performance Model/Rows of modules in array & 1 \\
\hline Depreciation/Federal Straight Line Depreciation Years & 20 \\
\hline Inverter (Sandia)/Sandia Inverter & $\begin{array}{l}\text { SAM/Sandia Inverters/Power-One Inc.: } \\
\text { PVI-12.0-I-OUTD-x-US-480-y 480V [CEC 2011] }\end{array}$ \\
\hline Inverter (Sandia)/Sandia Inverter & $\begin{array}{l}\text { SAM/Sandia Inverters/SMA America: SB4000US } \\
\text { 240V [CEC 2007] }\end{array}$ \\
\hline Inverter Datasheet/ Manufacturer efficiency (\%) & 96 \\
\hline Inverter Datasheet/Maximum AC output power (Wac) & 12441.6 \\
\hline Inverter Datasheet/Maximum DC current (Adc) & 36 \\
\hline Inverter Datasheet/Maximum DC voltage (Vdc) & 900 \\
\hline Inverter Datasheet/Maximum MPPT DC voltage (Vdc) & 750 \\
\hline Inverter Datasheet/Minimum MPPT DC voltage (Vdc) & 360 \\
\hline Inverter Datasheet/Nominal AC voltage (Vac) & 400 \\
\hline Inverter Datasheet/Nominal DC voltage (Vdc) & 360 \\
\hline Inverter Datasheet/Power consumption at night (Wac) & 3.1104 \\
\hline $\begin{array}{l}\text { Inverter Datasheet/Power consumption during } \\
\text { operation }(\mathrm{Wdc})\end{array}$ & 0 \\
\hline Inverter Datasheet/Weighted efficiency (\%) & 97.2 \\
\hline $\begin{array}{l}\text { Inverter Part Load Curve/Maximum AC } \\
\text { output power (Wac) }\end{array}$ & 36,000 \\
\hline Inverter Part Load Curve/Maximum DC current (Adc) & 150 \\
\hline Inverter Part Load Curve/Maximum DC voltage (Vdc) & 600 \\
\hline
\end{tabular}


Table A5. Cont.

\begin{tabular}{|c|c|}
\hline Input Variable & Value \\
\hline $\begin{array}{l}\text { Inverter Part Load Curve/Maximum MPPT DC } \\
\text { voltage }(\mathrm{Vdc})\end{array}$ & 480 \\
\hline $\begin{array}{l}\text { Inverter Part Load Curve/Minimum MPPT DC } \\
\text { voltage (Vdc) }\end{array}$ & 250 \\
\hline Inverter Part Load Curve/Nominal AC voltage (Vac) & 240 \\
\hline Inverter Part Load Curve/Nominal DC voltage (Vdc) & 310 \\
\hline $\begin{array}{l}\text { Inverter Part Load Curve/Power consumption } \\
\text { at night (Wac) }\end{array}$ & 0.6 \\
\hline Inverter Part Load Curve/Weighted Efficiency Type & CEC efficiency \\
\hline Loan Parameters/Debt Fraction (\%) & 0 \\
\hline Loan Parameters/Loan Rate (\%/year) & 7.78 \\
\hline Loan Parameters/Loan Term (years) & 15 \\
\hline Location and Resource/Location & $\begin{array}{l}\text { C:IUsers\Fisher \Desktop } \backslash \text { SAM weather } \\
\text { data/AUS_QLD.Brisbane.945780_IWEC.epw }\end{array}$ \\
\hline $\mathrm{O}$ and M Costs/Fixed Cost by Capacity (\$/kW-year) & 12 \\
\hline PV Array Self-Shading/Mask Angle Calculation Method & Average over Entire Array \\
\hline PV Array Self-Shading/Number of Bypass Diodes & 3 \\
\hline PV Array Self-Shading/Number of Cells along Width & 6 \\
\hline PV Array Self-Shading/Number of Modules along Side & 1 \\
\hline PV Array Self-Shading/Number of Strings along Bottom & 1 \\
\hline PV Array Self-Shading/Orientation & Portrait \\
\hline PV Array Self-Shading/Row Spacing $(\mathrm{m})$ & 5 \\
\hline PV Array Self-Shading/Width (m) & 0.992 \\
\hline PV Array/AC wiring losses $((0 . .1))$ & 0.97 \\
\hline PV Array/Desired array size $(\mathrm{kWdc})$ & 1202 \\
\hline PV Array/Mode & Specify desired array size \\
\hline PV Array/Modules per string & 40 \\
\hline PV Array/Monthly ground reflectance (albedo) & 0.2 \\
\hline PV Array/Number of inverters & 88 \\
\hline $\begin{array}{l}\text { PV Array/PV Radiation Model }(0=\text { Total\&Beam } \\
1=\text { Beam\&Diffuse })\end{array}$ & 0 \\
\hline $\begin{array}{l}\text { PV Array/PV Tilt Radiation Model } \\
(0=\text { Isotropic } 1=\text { HDKR } 2=\text { Perez })\end{array}$ & Perez \\
\hline PV Array/Packing factor & 1.05 \\
\hline PV Array/Row offset $(\mathrm{m})$ & 0 \\
\hline PV Array/Step-up transformer losses $((0 . .1))$ & 1 \\
\hline PV Array/Strings in parallel & 125 \\
\hline PV Array/Use albedo in weather file if it exists & 1 \\
\hline $\begin{array}{l}\text { PV Capital Costs/Balance of System Equipment } \\
\text { Capacity }(\$ / \mathrm{Wdc})\end{array}$ & 0.219 \\
\hline PV Capital Costs/Contingency & 5 \\
\hline PV Capital Costs/Engineering Cost, by Capacity ( $\$ / \mathrm{Wdc})$ & 0.14 \\
\hline
\end{tabular}


Table A5. Cont.

\begin{tabular}{|c|c|}
\hline Input Variable & Value \\
\hline $\begin{array}{l}\text { PV Capital Costs/Grid Interconnect Cost, } \\
\text { by Capacity }(\$ / W d c)\end{array}$ & 0.13 \\
\hline PV Capital Costs/Installation Labor, by Capacity (\$/Wdc) & 0.625 \\
\hline $\begin{array}{l}\text { PV Capital Costs/Installer Margin and Overhead, } \\
\text { by Capacity }(\$ / W d c)\end{array}$ & 0.625 \\
\hline PV Capital Costs/Inverter Cost & 0.5 \\
\hline PV Capital Costs/Module Cost & 1.53 \\
\hline PV Capital Costs/Permitting Cost, by Capacity $(\$ / \mathrm{Wdc})$ & 0.06 \\
\hline $\begin{array}{l}\text { PV Inverter/Inverter Model Type }(0=\mathrm{CEC} \\
1=\text { DATASHEET, } 3=\text { PARTLOAD })\end{array}$ & 1 \\
\hline $\begin{array}{l}\text { PV Module Manufacturer Specifications } \\
\text { Model/Approximate installation height }\end{array}$ & Two story building height or higher \\
\hline PV Module Manufacturer Specifications Model/Cell type & Multi-Si \\
\hline $\begin{array}{l}\text { PV Module Manufacturer Specifications } \\
\text { Model/Maximum power point current (Imp) (A) }\end{array}$ & 6 \\
\hline $\begin{array}{l}\text { PV Module Manufacturer Specifications } \\
\text { Model/Maximum power point voltage (Vmp) (V) }\end{array}$ & 30 \\
\hline $\begin{array}{l}\text { PV Module Manufacturer Specifications Model/Module } \\
\text { area (m2) }\end{array}$ & 1.3 \\
\hline $\begin{array}{l}\text { PV Module Manufacturer Specifications } \\
\text { Model/Module description }\end{array}$ & Generic polycrystalline silicon module \\
\hline $\begin{array}{l}\text { PV Module Manufacturer Specifications Model/Nominal } \\
\text { operating cell temperature ('C) }\end{array}$ & 46 \\
\hline $\begin{array}{l}\text { PV Module Manufacturer Specifications Model/Number } \\
\text { of cells in series }\end{array}$ & 60 \\
\hline $\begin{array}{l}\text { PV Module Manufacturer Specifications Model/Open } \\
\text { circuit voltage }(\mathrm{Voc})(\mathrm{V})\end{array}$ & 37 \\
\hline $\begin{array}{l}\text { PV Module Manufacturer Specifications Model/Short } \\
\text { circuit current (Isc) (A) }\end{array}$ & 7 \\
\hline $\begin{array}{l}\text { PV Module Manufacturer Specifications } \\
\text { Model/Standoff height }\end{array}$ & Ground or rack mounted \\
\hline $\begin{array}{l}\text { PV Module Manufacturer Specifications } \\
\text { Model/Temperature coefficient of Isc }\end{array}$ & 0.004 \\
\hline $\begin{array}{l}\text { PV Module Manufacturer Specifications } \\
\text { Model/Temperature coefficient of Voc }\end{array}$ & -0.11 \\
\hline $\begin{array}{l}\text { PV Module Manufacturer Specifications } \\
\text { Model/Temperature coefficient of max. } \\
\text { power point }(\% / / \mathrm{C})\end{array}$ & -0.41 \\
\hline $\begin{array}{l}\text { PV Module/Module Model Type } \\
(0=\text { MPE } 1=\text { CEC } 2=\text { CECUSER } 3=\text { SANDIA })\end{array}$ & 1 \\
\hline PV Subarray 1/Azimuth 1 (deg) & 20 \\
\hline PV Subarray 1/DC wiring losses $1(\%)$ & 0.98 \\
\hline PV Subarray 1/Diode and connection losses $1(\%)$ & 0.995 \\
\hline PV Subarray $1 /$ Ground coverage ratio 1 & 0.3 \\
\hline
\end{tabular}


Table A5. Cont.

\begin{tabular}{|c|c|}
\hline $\begin{array}{c}\text { Input Variable } \\
\end{array}$ & Value \\
\hline PV Subarray 1/Mismatch losses $1(\%)$ & 0.98 \\
\hline PV Subarray 1/Nameplate derate $1(\%)$ & 1 \\
\hline PV Subarray $1 /$ Self-shading mode for $1 \mathrm{x}$ trackers & Self-shaded \\
\hline PV Subarray $1 /$ Tilt $1(\mathrm{deg})$ & 4 \\
\hline PV Subarray $1 /$ Tracker rotation limit $1(\mathrm{deg})$ & 45 \\
\hline PV Subarray $1 /$ Tracking error $1(\%)$ & 1 \\
\hline PV Subarray $1 /$ Tracking mode 1 & Fixed \\
\hline $\begin{array}{l}\text { Performance Adjustment/Year-to-year decline in output } \\
\text { (compounded annually) }\end{array}$ & 0.7 \\
\hline Sandia Inverter Model/Maximum AC power (Wac) & 12,000 \\
\hline Sandia Inverter Model/Maximum DC current (Adc) & 25 \\
\hline Sandia Inverter Model/Maximum DC power (Wdc) & $12,363.9$ \\
\hline Sandia Inverter Model/Maximum DC voltage (Vdc) & 520 \\
\hline $\begin{array}{l}\text { Sandia Inverter Model/Maximum } \\
\text { MPPT DC voltage }(\mathrm{Vdc})\end{array}$ & 470 \\
\hline $\begin{array}{l}\text { Sandia Inverter Model/Minimum } \\
\text { MPPT DC voltage (Vdc) }\end{array}$ & 250 \\
\hline Sandia Inverter Model/Nominal AC voltage (Vac) & 480 \\
\hline Sandia Inverter Model/Nominal DC voltage (Vdc) & 374.028 \\
\hline $\begin{array}{l}\text { Sandia Inverter Model/Power } \\
\text { consumption at night }(\mathrm{Wac})\end{array}$ & 0.4 \\
\hline $\begin{array}{l}\text { Sandia Inverter Model/Power consumption } \\
\text { during operation }\end{array}$ & $69.199(\mathrm{Wdc})$ \\
\hline Sandia PV Array Performance Model/Material & Mc-Si \\
\hline $\begin{array}{l}\text { Sandia PV Array Performance } \\
\text { Model/Module Area }\left(\mathrm{m}^{2}\right)\end{array}$ & 1.312 \\
\hline Sandia PV Array Performance Model/Module Name & $\begin{array}{l}\text { SAM/Sandia Modules/Advent } \\
\text { Solar AS160 [2006] }\end{array}$ \\
\hline $\begin{array}{l}\text { Sandia PV Array Performance Model/Module Structure } \\
\text { and Mounting }\end{array}$ & Use Database Values \\
\hline $\begin{array}{l}\text { Sandia PV Array Performance Model/Number of Cell } \\
\text { Strings in Parallel }\end{array}$ & 1 \\
\hline $\begin{array}{l}\text { Sandia PV Array Performance Model/Number of } \\
\text { Cells in Series }\end{array}$ & 72 \\
\hline Sandia PV Array Performance Model/Vintage & 2006 \\
\hline Sandia PV Array Performance Model/a & -99 \\
\hline String Wiring & Horizontal \\
\hline Utility Rate/Flat Buy Rate $(\$ / \mathrm{kWh})$ & 0.125 \\
\hline Utility Rate/Flat Sell Rate $(\$ / \mathrm{kWh})$ & 0.125 \\
\hline Utility Rate/Out-year Escalation (\%/year) & 1.82 \\
\hline Utility Rate/Year End Sell Rate $(\$ / \mathrm{kWh})$ & 0.0289 \\
\hline
\end{tabular}




\section{System Advisor Model Report}

Photovoltaic System

Commercial
1.2 DC Mư Nameplate

$\$ 3.96$ Mú Installed Cost
BRISBANE, -

$-27.38 \mathrm{~N}, 153.1 \mathrm{E}$ GMT +10

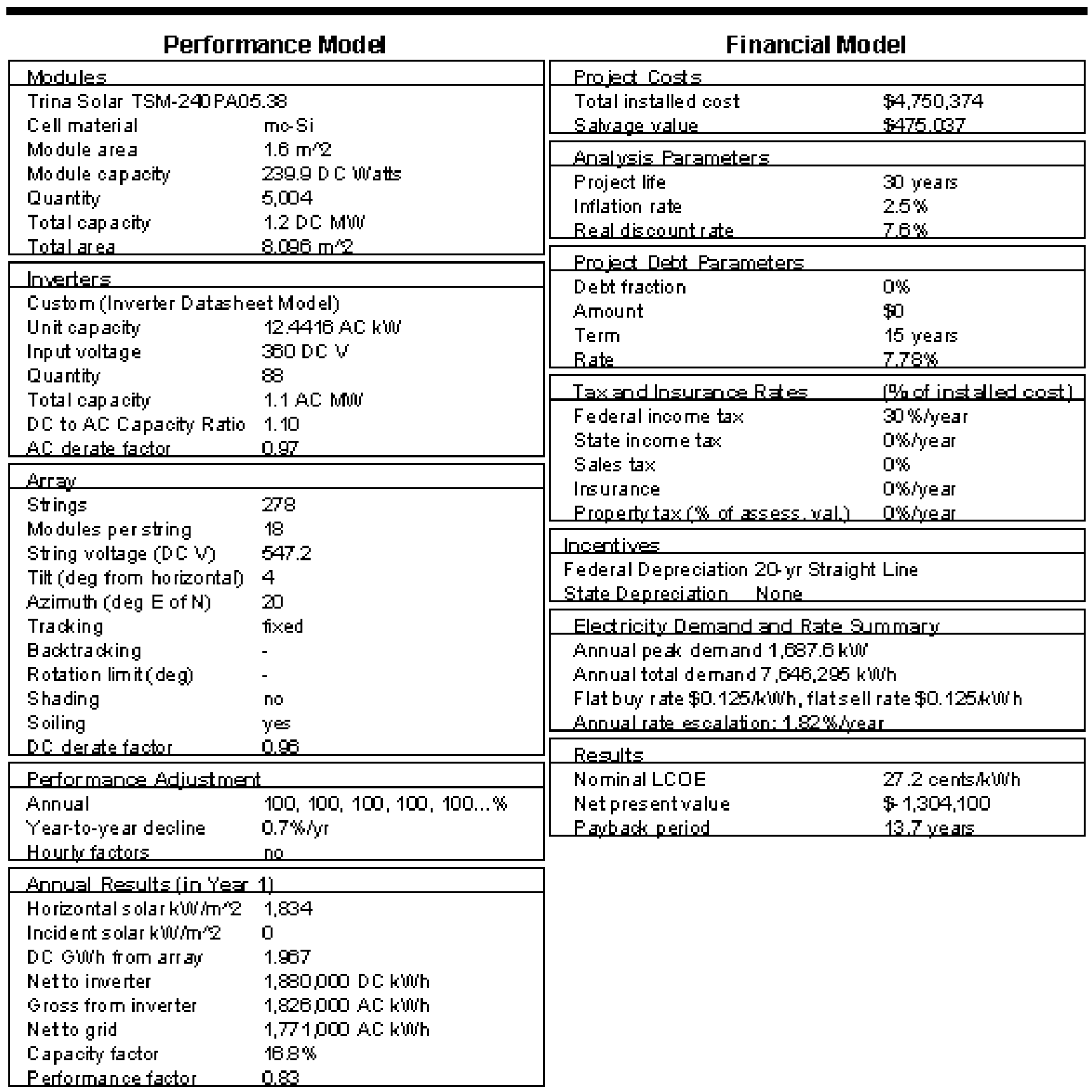



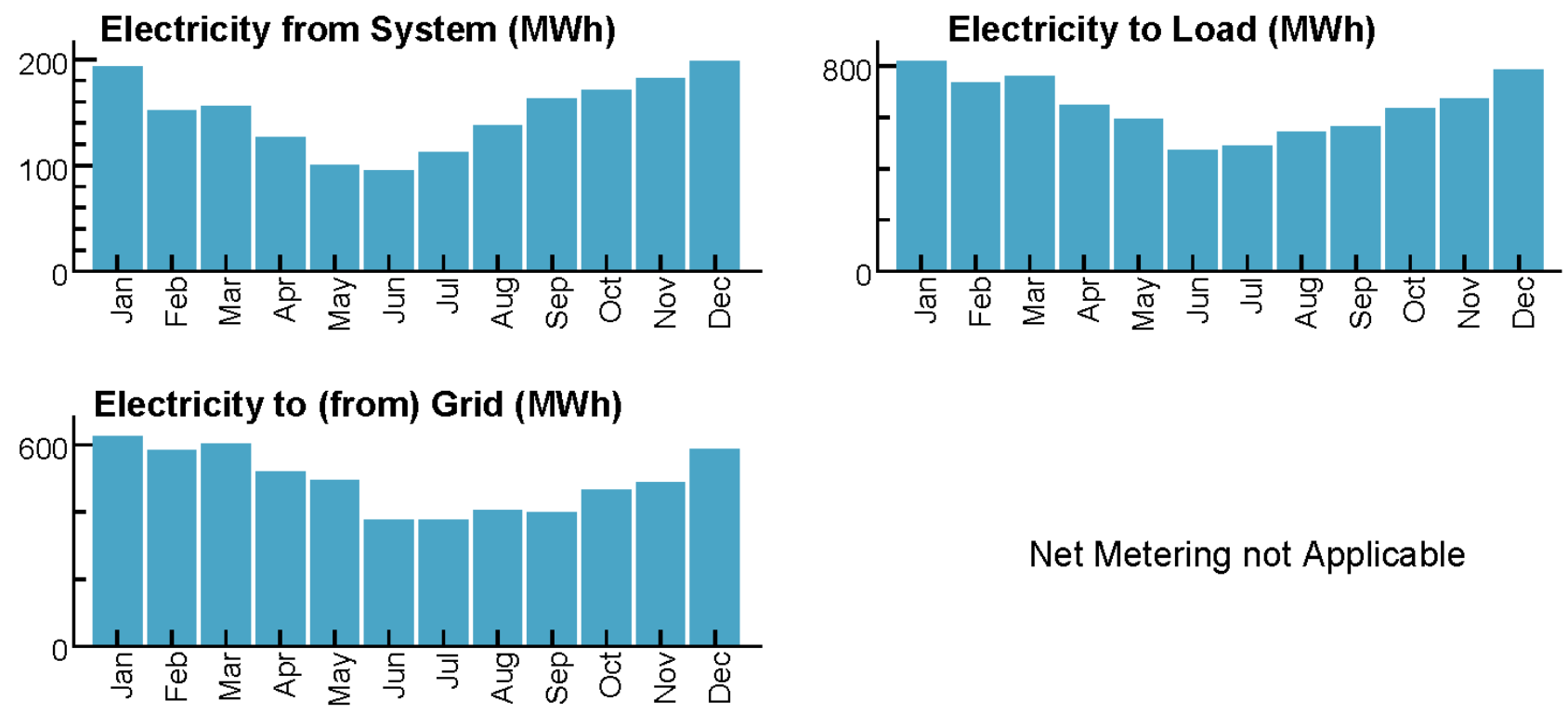

Net Metering not Applicable

Monthly Electricity Purchases and Savings (Year 1 \$)

\begin{tabular}{|rrrr|}
\hline Month & Without System & With System & Savings \\
\hline Jan & 146,063 & 111,347 & 34,716 \\
Feb & 130,926 & 103,677 & 27,249 \\
Mar & 134,841 & 106,979 & 27,862 \\
Apr & 114,507 & 92,169 & 22,337 \\
May & 104,985 & 87,431 & 17,553 \\
Jun & 88,722 & 70,757 & 17,965 \\
Jul & 91,256 & 70,266 & 20,989 \\
Aug & 102,252 & 76,449 & 25,802 \\
Sep & 105,085 & 74,850 & 30,234 \\
Oct & 120,132 & 88,113 & 32,018 \\
Nov & 119,061 & 86,806 & 32,254 \\
Dec & 139,331 & 103,979 & 35,352 \\
Annual & $1,397,167$ & $1,072,829$ & 324,338 \\
\hline
\end{tabular}

\section{NPV Approximation using Annuities}

\begin{tabular}{|c|c|c|}
\hline \multicolumn{3}{|c|}{ Annuities, Capital Recovery Factor $(C R F)=0.1087$} \\
\hline Investment & $\$-516,100$ & Sum: \\
\hline Expenses & $\$-12,300$ & $\$-141,700$ \\
\hline Savings & $\$ 68,300$ & NPV = Sum / CRF \\
\hline Energy value & $\$ 318,400$ & $\$-1,304,000$ \\
\hline
\end{tabular}

Investment $=$ Installed Cost - Debt Principal $-|B|-C B \mid$ Expenses $=$ Operating Costs + Debt Payments Savings $=$ Tax Deductions $+\mathrm{PBI}$

Energy value $=$ Tax Adjusted Net Savings Nominal discount rate $=10.29 \%$

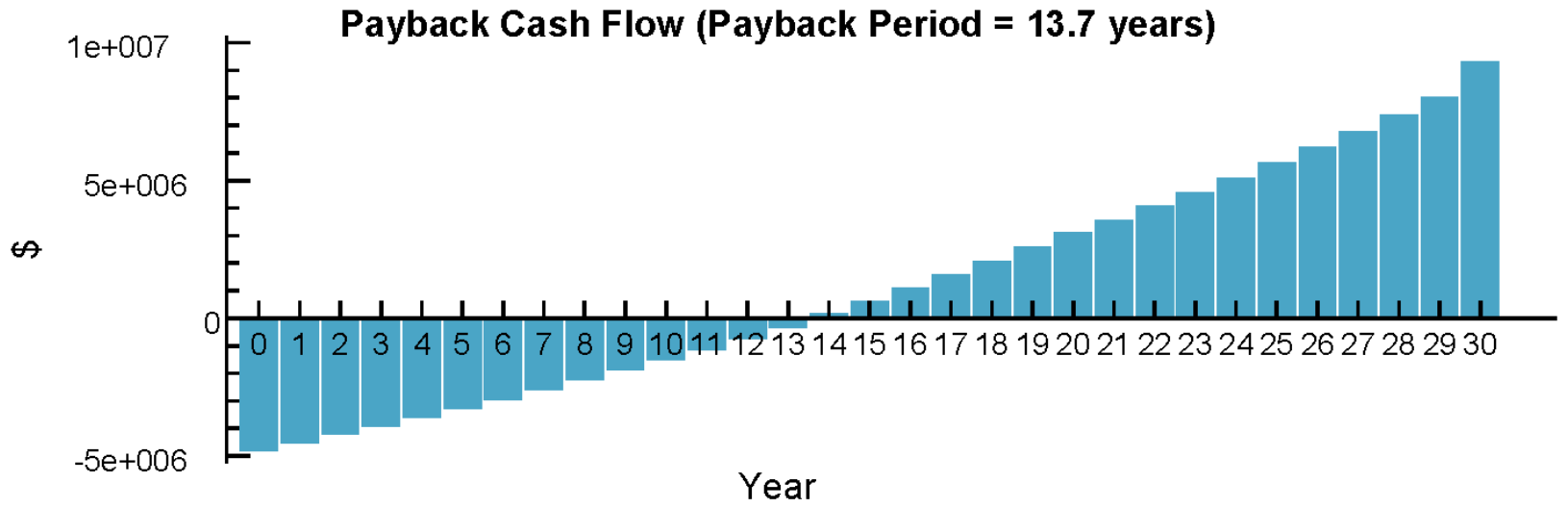

Figure A1. Cont. 
Nominal POA Total Radiation

15,185,631 kWh

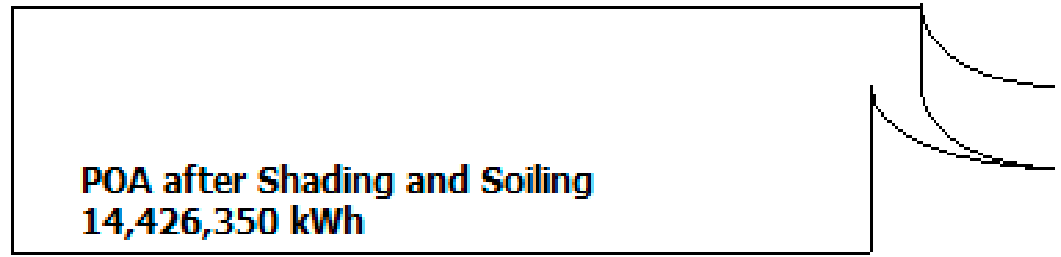

Array Nominal Output at STC

2,138,595 kWh(dc)

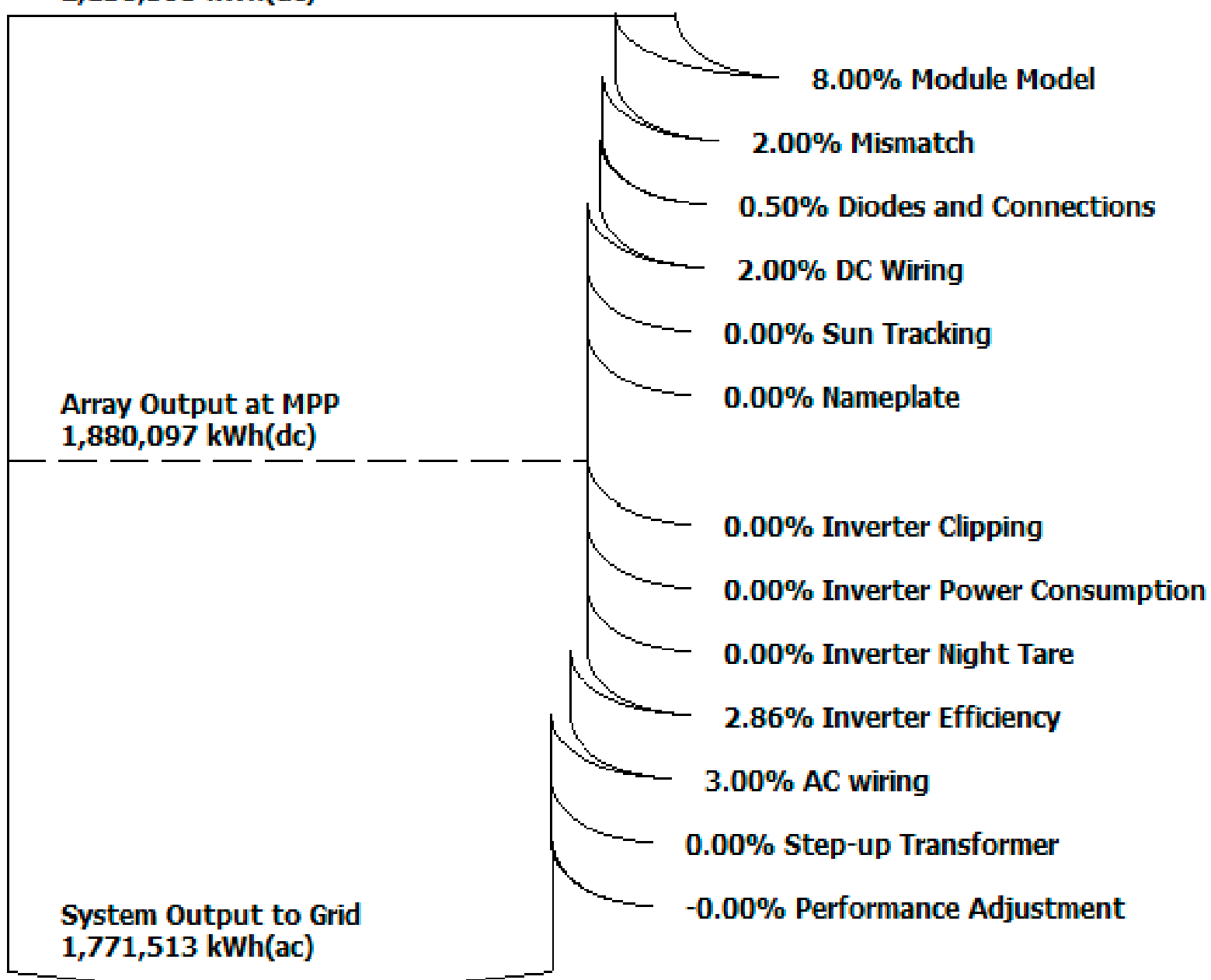

Figure A1. System advisor model report for UQ Solar life cycle costing analysis. 


\section{Conflicts of Interest}

The authors declare no conflict of interest.

\section{References}

1. Che, N.; Feng, A.; McCluskey, C.; Pham, P.; Willcock, T.; Stanwix, G. 2013 Australian Energy Update; Bureau of Resources and Energy Economics (BREE): Canberra, Australia, 2013.

2. Geoscience Australia and ABARE. Australian Energy Resource Assessment; Geoscience Australia and ABARE: Canberra, Australia, 2010.

3. BREE. Energy in Australia 2013; BREE: Canberra, Australia, 2013.

4. Finkbeiner, M.; Schau, E.M.; Lehmann, A.; Traverso, M. Towards life cycle sustainability assessment. Sustainability 2010, 2, 3309-3322.

5. Kloepffer, W. Life cycle sustainability assessment of products (with comments by Helias A. Udo de Haes). Int. J. Life Cycle Assess. 2008, 13, 89-95.

6. Zamagni, A.; Buttol, P.; Buonamici, R.; Masoni, P.; Guinee, J.B.; Huppes, G.; Heijungs, R.; van der Voet, E.; Ekvall, T.; Rydberg, T. D20 Blue Paper on Life Cycle Sustainability Analysis (Revision 1 after the Open Consultation). Available online: http://www.leidenuniv.nl/cml/ ssp/publications/calcas_report_d20.pdf(accessed on 19 January 2015).

7. Halog, A.; Manik, Y. Advancing integrated systems modelling framework for life cycle sustainability assessment. Sustainability 2011, 3, 469-499.

8. UNEP/SETAC Life Cycle Initiative. Towards a Life Cycle Sustainability Assessment-Making Informed Choices on Products. Available online: http://www.unep.org/pdf/UNEP_LifecycleInit_ Dec_FINAL.pdf (accessed on 19 January 2015).

9. Alsema, E.A. Energy pay-back time and $\mathrm{CO}_{2}$ emissions of PV Systems. Prog. Photovolt. Res. Appl. 2000, 8, 17-25.

10. Meijer, A. Life-cycle assessment of photovoltaic modules: Comparison of mc-Si, InGaP and InGaP/mc-Si solar modules. Prog. Photovolt. Res. Appl. 2003, 11, 275-287.

11. Jungbluth, N. Life cycle assessment of crystalline photovoltaics in the Swiss ecoinvent database. Prog. Photovolt. Res. Appl. 2005, 13, 429-446.

12. Alsema, E.; de Wild-Scholten, M. Environmental impact of crystalline silicon photovoltaic module production. In Proceedings of the Material Research Society Fall Meeting, Symposium G: Life Cycle Analysis Tools for "Green" Materials and Process Selection, Boston, MA, USA, 28-30 November 2005.

13. Fthenakis, V.; Alsema, E. Photovoltaics energy payback times, greenhouse gas Emissions and external costs: 2004-early 2005 status. Prog. Photovolt. Res. Appl. 2006, 14, 275-280.

14. De Wild-Scholten, M.J. Renewable and Sustainable. In Proceedings of the CrystalClear Final Event, Munich, Germany, 26 May 2009.

15. Fthenakis, V.M. Sustainability metrics for extending thin-film photovoltaics to terawatt levels. MRS Bull. 2012, 37, 425-430.

16. APVI. Mapping Australian Photovoltaic Installations. Available online: http://pv-map.apvi.org.au/ historical\#4/-26.67/134.12 (accessed on 15 April 2014). 
17. UQ Solar. Available online: http://uq.edu.au/solarenergy/ (accessed on 20 April 2014).

18. Watt, M.; Passey, R. PV in Australia 2012. Available online: http://apvi.org.au/wp-content/ uploads/2013/11/Australian-PV-Report-2012.pdf (accessed on 19 January 2015).

19. Ecoinvent. Available online: http://www.ecoinvent.ch (accessed on 4 May 2014).

20. Australia Greenhouse Office. RMY Australia Representative Meteorological Year Climate Files; Department of the Environment and Water Resources, Commonwealth of Australia: Canberra, Australia, 2006.

21. Australian PV Association (APVA). Modelling of PV and Electricity Prices in the Australian Commercial Sector; Australian PV Association (APVA): Canberra, Australia, 2011.

22. BREE. Australia Energy Technology Assessment; BREE: Canberra, Australia, 2012.

23. AUSTELA. Australian Companion Guide to SAM for Concentrating Solar Power. Available online: http://austela.com.au/docs/projects/sam/SAM_for_Aus_Companion_Guide_20140306.pdf (accessed on 19 January 2015).

24. Fthenakis, V.; Frischknecht, R.; Raugei, M.; Kim, H.C.; Alsema, E.; Held, M.; de Wild-Scholten, M. Methodology Guidelines on Life Cycle Assessment of Photovoltaic Electricity. Available online: http://www.seas.columbia.edu/clca/IEA_Task12_LCA_Guidelines_12_1_11_Latest.pdf (accessed on 19 January 2015).

25. TrinaSolar. Available online: http://www.trinasolar.com/ (accessed on 23 April 2014).

26. Fthenakis, V.; Kim, H.C.; Frischknecht, R.; Raugei, M.; Sinha, P.; Stucki, M. Life Cycle Inventories and Life Cycle Assessment of Photovoltaic Systems; International Energy Agency (IEA) PVPS Task 12, Report T12-02; International Energy Agency (IEA): New York, NY, USA, 2011.

27. Jungbluth, N.; Stucki, M.; Frischknecht, R. Final Report No. 6 Ecoinvent v2.1; Bauer, C., Ed.; Swiss Centre for LCI, PSI: Villigen, Switzerland, 2009; Volume 6.

28. Ecoinvent. Allocation, Cut-off by Classification. Available online: http://www.ecoinvent.org/ database/ecoinvent-version-3/system-models/allocation-cut-off-by-classification/ (accessed on 2 May 2014).

29. Fthenakis, V.M.; Kim, H.C. Photovoltaics: Life-cycle analyses. Sol. Energy 2011, 85, 1609-1628.

30. Fthenakis, V. Overview of potential hazards. In Practical Handbook of Photovoltaics: Fundamentals and Applications; Markvart, T., Castaner, L., Eds.; Elsevier: Oxford, UK, 2003; pp. 857-868.

31. Fuller, S.K.; Petersen, S.R. NIST Handbook 135 Life-Cycle Costing Manual for the Federal Energy Management Program; U.S. Government Printing Office: Washington, DC, USA, 1996.

32. APVA. Development of a Strategic Planning Model for ASI to Assist Further Development of the Australian PV Sector; APVA: Richmond, VA, USA, 2010.

33. Stanford University. Guidelines for Life Cycle Cost Analysis; Stanford University: Stanford, CA, USA, 2005.

34. NREL. System Advisor Model (SAM)'s Help System; NREL: Golden, CO, USA, 2014.

35. Energex Limited. PeakSmart Time of Use Tariff; Energex Limited: Brisbane, Australia, 2012.

36. Trina Solar. Corporate Social Responsibility Report; Trina Solar: Changzhou, China, 2012.

37. SVTC. Toward a just and Sustainable Solar Energy Industry. A Silicon Valley Toxics Coalition White Paper; SVTC: San Francisco, CA, USA, 2009.

38. SVTC. A Project of the Silicon Valley Toxics Coalition; 2013 Solar Scorecard; SVTC: San Francisco, CA, USA, 2013. 
39. Byrnes, L.; Brown, C.; Foster, J.; Wagner, L. Australian renewable energy policy: Barriers and challenges. Renew. Energ. 2013, 60, 711-721.

40. DERM. ClimateQ: Toward a Greener Queensland; DERM: Brisbane, Australia, 2009.

41. Berrill, T. Clean Energy Pathways? A Review of Energy Policy in Queensland with a Regional Case Study of the Impacts on the Felton Valley. Available online: http://r.search.yahoo.com/ ylt=A86.J3U16L1U3kAAN5ElnIlQ; ylu=X3oDMTEzY3Nia2wzBHN1YwNzcgRwb3MDMQRjb2 xvA2dxMQR2dGlkA11IUzAwM18x/RV=2/RE=1421760694/RO=10/RU=http\%3a\%2f\%2fxa.yimg.c om\%2fkq\%2fgroups \%2f17964577\%2f690092342\%2fname\%2fClean\%2bEnergy\%2bPathways\%2b\%2bQld\%2bEnergy\%2bPolicy\%2bReview\%2bV2.pdf/RK=0/RS=GSYJ7eFw9J235x5IfeL1ZWr8 6xI- (accessed on 19 January 2015).

42. APVA. A Distributed Energy Market: Consumer \& Utility Interest, and the Regulatory Requirements. Available online: http://apvi.org.au/a-distributed-energy-market-consumer-utilityinterest-and-the-regulatory-requirements/ (accessed on 19 January 2015).

43. Pinderhughes, R. Green Collar Jobs; Berkeley Office of Energy and Sustainable Development: Berkeley, CA, USA, 2007.

44. Energymatters. Available online: http://store.energymatters.com.au/brand/abb/products/inverters (accessed on 27 April 2014).

(C) 2015 by the authors; licensee MDPI, Basel, Switzerland. This article is an open access article distributed under the terms and conditions of the Creative Commons Attribution license (http://creativecommons.org/licenses/by/4.0/). 